Geological Society of America

Memoir 198

2006

\title{
Proterozoic sedimentary exhalative (SEDEX) deposits and links to evolving global ocean chemistry
}

\author{
Timothy W. Lyons* \\ Anne M. Gellatly \\ Department of Earth Sciences, University of California, Riverside, California 92521, USA \\ Peter J. McGoldrick \\ CODES, ARC Centre of Excellence in Ore Deposits, University of Tasmania, Hobart, TAS 7001, Australia \\ Linda C. Kah \\ Department of Earth \& Planetary Sciences, University of Tennessee, Knoxville, Tennessee 37996, USA
}

\begin{abstract}
Sedimentary exhalative (SEDEX) Zn-Pb-sulfide mineralization first occurred on a large scale during the late Paleoproterozoic. Metal sulfides in most Proterozoic deposits have yielded broad ranges of predominantly positive $\delta^{34} \mathrm{~S}$ values traditionally attributed to bacterial sulfate reduction. Heavy isotopic signatures are often ascribed to fractionation within closed or partly closed local reservoirs isolated from the global ocean by rifting before, during, and after the formation of Rodinia. Although such conditions likely played a central role, we argue here that the first appearance of significant SEDEX mineralization during the Proterozoic and the isotopic properties of those deposits are also strongly coupled to temporal evolution of the amount of sulfate in seawater.

The ubiquity of ${ }^{34} \mathrm{~S}$-enriched sulfide in ore bodies and shales and the widespread stratigraphic patterns of rapid $\delta^{34} \mathrm{~S}$ variability expressed in both sulfate and sulfide data are among the principal evidence for global seawater sulfate that was increasing during the Proterozoic but remained substantially lower than today. Because sulfate is produced mostly through weathering of the continents in the presence of oxygen, low Proterozoic concentrations imply that levels of atmospheric oxygen fell between the abundances of the Phanerozoic and the deficiencies of the Archean, which are also indicated by the Precambrian sulfur isotope record. Given the limited availability of atmospheric oxygen, deep-water anoxia may have persisted well into the Proterozoic in the presence of a growing sulfate reservoir, which promoted prevalent euxinia. Collectively, these observations suggest that the mid-Proterozoic maximum in SEDEX mineralization and the absence of Archean deposits reflect a critical threshold in the accumulation of oceanic sulfate and thus sulfide within anoxic bottom waters and pore fluids - conditions that favored both the production and preservation of sulfide mineralization at or just below the seafloor. Consistent with these evolving global conditions, the appearance of voluminous SEDEX mineralization ca. 1800 Ma coincides generally with the disappearance of banded iron formations-marking the transition from an early iron-dominated ocean to one more strongly influenced by sulfide availability.
\end{abstract}

\footnotetext{
*timothy.lyons@ucr.edu
}

Lyons, T.W., Gellatly, A.M., McGoldrick, P.J., and Kah, L.C., 2006, Proterozoic sedimentary exhalative (SEDEX) deposits and links to evolving global ocean chemistry, in Kesler, S.E., and Ohmoto, H., eds., Evolution of Early Earth's Atmosphere, Hydrosphere, and Biosphere-Constraints from Ore Deposits: Geological Society of America Memoir 198, p. 169-184, doi: 10.1130/2006.1198(10). For permission to copy, contact editing@geosociety.org. (C2006 Geological Society of America. All rights reserved. 


\begin{abstract}
In further agreement with this conceptual model, Proterozoic SEDEX deposits in northern Australian formed from relatively oxidized fluids that required reduced conditions at the site of mineralization. By contrast, the generally more oxygenated Phanerozoic ocean may have only locally and intermittently favored the formation and preservation of exhalative mineralization, and most Phanerozoic deposits formed from reduced fluids that carried some sulfide to the site of ore precipitation.
\end{abstract}

Keywords: Proterozoic, SEDEX deposits, sulfur isotopes, ocean chemistry, atmospheric oxygenation.

\section{INTRODUCTION}

Sedimentary exhalative (SEDEX) deposits are sulfide-dominated $\mathrm{Pb}-\mathrm{Zn}$ ore bodies with sphalerite and galena as the principal ore minerals. Although the specifics of this deposit type are complex (Goodfellow et al., 1993; Lydon, 1996; Large et al., 2004), formation through submarine venting of hydrothermal fluids in structurally controlled (rifted) sedimentary basins are universal characteristics. The compilations of Goodfellow et al. (1993) and Lydon (1996) show us that SEDEX mineralization spans a broad portion of geologic time - ranging from ca. $1800 \mathrm{Ma}$ to possible analogues forming today-however, peak abundances are well expressed during discrete intervals of the mid-Proterozoic (1800-1600 Ma) and late Proterozoic to Paleozoic (600-300 Ma). A clear maximum in ore tonnage is observed between 1700 and ca. $1600 \mathrm{Ma}$.

Despite this broad temporal distribution, Lydon (1996, p. 141) found the lack of early Proterozoic and Archean SEDEX deposits to be enigmatic:

There does not appear to be any compelling reason, based on current understanding, why Sedex deposits should not occur in rocks older than Middle Proterozoic [late Paleoproterozoic]. The onset of the Middle Proterozoic does not seem to coincide with any major permanent change in global climate, ocean water composition, atmosphere composition, or geotectonic processes.

The purpose of this report is to revisit this assertion within the context of the most recent studies of Precambrian oceanatmosphere chemistry and, in doing so, suggest why such a gap is precisely what the models for early Earth predict. It is not our intent, however, to provide a comprehensive survey of SEDEX mineralization or to develop a model that precludes the possibility of exceptions. Instead, we will suggest that the first-order patterns, and in particular the absence of Archean deposits and the abundance of SEDEX mineralization of Proterozoic age, are completely consistent with a now widely held view of evolving Precambrian ocean chemistry. The essential Proterozoic controls include the first appearance of quantitatively significant sulfate in the ocean, the persistence of deep water oxygen deficiency, the widespread distribution of bacterial hydrogen sulfide within the ocean and underlying sediments, and possibly abundant methane within the Proterozoic ocean-atmosphere system. All of these parameters will be viewed in light of the pronounced ${ }^{34} \mathrm{~S}$ enrichments that dominate the metal sulfides of most mid-Proterozoic SEDEX mineralization. More challenging is an explanation of the distribution of major SEDEX mineralization in younger sediments. Tectonic influences, specifically the temporally varying extent of continental rifting, are always the essential backdrop to SEDEX hydrothermal processes. However, in the Phanerozoic, as for the Precambrian, depositional redox may have played a central role in controlling the amount and preservation of metal sulfide accumulation on the seafloor.

\section{BACKGROUND}

\section{SEDEX Deposits}

The many details of sedimentary exhalative sulfide deposits, including genetic models, are ably reviewed in Goodfellow et al. (1993), Lydon (1996), and Large et al. (2004) and are only briefly summarized here. SEDEX deposits are marked by stratiform, sediment-hosted $\mathrm{Zn}$-Pb-sulfide mineralization, with sphalerite and galena as the principal ore minerals and pyrite typically as the most abundant sulfide phase. These deposits form in sedimentary basins through submarine venting of hydrothermal fluids. SEDEX mineralization is essentially synsedimentary-forming at or just below the seafloor within fault-controlled basins or troughs that are most often related to major intracratonic or continental margin rift zones - although mineralization often postdates the most active phase of rifting (Lydon, 1996),

The deposits range in age from ca. $1800 \mathrm{Ma}$ to possible modern analogues but cluster in two groups: 1800-1600 and 600-300 Ma (Fig. 1). Most Proterozoic deposits formed between ca. 1700 and ca. $1600 \mathrm{Ma}$, which, from the standpoint of ore mass, is the dominant interval of all SEDEX-related $\mathrm{Zn}$ and $\mathrm{Pb}$ mineralization. Ore fluids are generally linked to metalliferous formational waters that were heated within the sedimentary basin under the elevated geothermal conditions of the typically extensional tectonic settings. The redox conditions of the basin lithologies exert an important control on the redox state of the metal-transporting fluids (Cooke et al., 2000). These workers distinguish two distinct classes of SEDEX $\mathrm{Zn}-\mathrm{Pb}$ deposits termed McArthur-type and Selwyn-type. Metal-transporting fluids for the former appear to have been relatively oxidized 

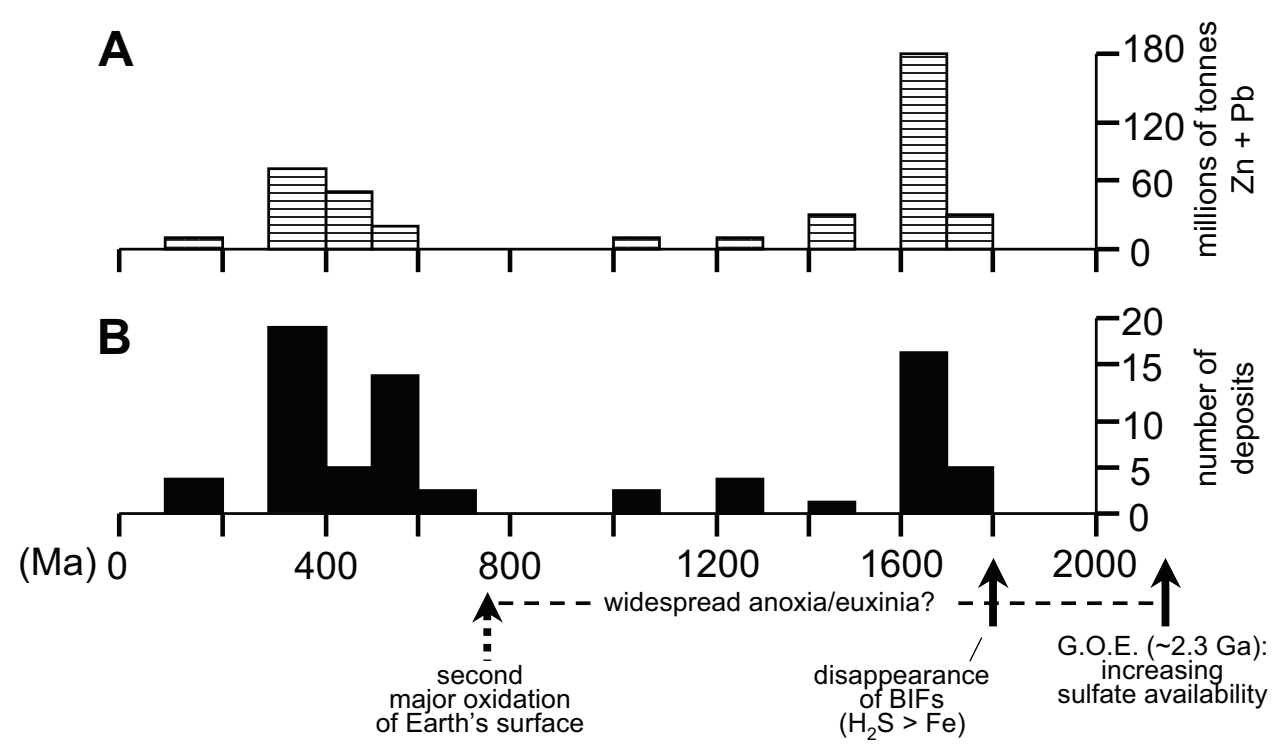

Figure 1. Age distribution of SEDEX mineralization as (A) tons of $\mathrm{Zn}$ and $\mathrm{Pb}$ per 100 m.y. interval and (B) number of deposits per 100 m.y. interval (after Lydon, 1996). Background for the interpretative details and related references are available in the text-including the G.O.E. (Great Oxidation Event).

(sulfate » sulfide), whereas the latter type formed from more reduced fluids (sulfide $\geq$ sulfate).

SEDEX deposits are well known for the large amounts of sulfur they contain, which is present in Proterozoic examples almost exclusively as pyrite, base metal sulfides, and pyrrhotite. Barite is much more common in the Phanerozoic deposits. Because the metal-rich ore fluids would by necessity be comparatively sulfide deficient, a substantial portion of the sulfide sulfur must be supplied independently at the site of mineralization. Bacterial reduction of seawater sulfate within anoxic pore fluids or a euxinic (anoxic and $\mathrm{H}_{2} \mathrm{~S}$-containing) water column is generally considered an essential source of that sulfide. When present, the $\delta^{34} \mathrm{~S}$ values of barite are generally consistent with a seawater sulfate source, suggesting barite formation by reaction between hydrothermal barium and sulfate in ambient seawater.

\section{Sulfur Isotopes}

Dissimilatory bacterial sulfate reduction (BSR) typically yields hydrogen sulfide that is strongly depleted in ${ }^{34} \mathrm{~S}$ relative to the ${ }^{34} \mathrm{~S} /{ }^{32} \mathrm{~S}$ ratio in the residual parent sulfate. Under pure-culture laboratory conditions, this sulfide can be depleted by up to $40 \%-45 \%$ relative to the sulfate (Chambers et al., 1975; Canfield, 2001; Detmers et al., 2001). Instantaneous fractionations of this magnitude are observed during BSR even at very low initial sulfate concentrations ranging down to $200 \mu \mathrm{M}$, or less than $1 \%$ of the concentration in modern seawater. Below $\sim 200 \mu \mathrm{M}$, rates of sulfate reduction are limited by sulfate transport across the bacterial cell membrane to the internal sites of enzymatically catalyzed fractionation. Under these conditions, most of the sulfate entering the cell is reduced, and the net fractionation is minimized (Canfield, 2001; Habicht et al., 2002).

The ${ }^{34} \mathrm{~S}$ depletions observed in Phanerozoic sedimentary sulfides can exceed $60 \%$, which may be larger than what is possible via BSR alone. A popular hypothesis for the extreme ${ }^{34} \mathrm{~S}$ depletions observed in low-temperature sulfide minerals invokes additional fractionation during bacterial disproportionation of elemental S and other S intermediates, which form through partial oxidation of $\mathrm{H}_{2} \mathrm{~S}$ (Canfield and Thamdrup, 1994; Habicht and Canfield, 2001; cf. Brunner and Bernasconi, 2005).

The net isotopic fractionation observed between sulfate and sulfide reflects both the collective effects of bacterial S reduction and disproportionation as well as the properties of the sulfate reservoir (Zaback et al., 1993). For example, even in the presence of large fractionations during BSR with coupled disproportionation reactions and diffusional inputs of sulfate, high $\delta^{34} \mathrm{~S}$ values for sulfate and sulfide can occur in pore-water and water-column systems with weak sulfate renewal relative to the rate of bacterial consumption. By contrast, low $\delta^{34} \mathrm{~S}$ values-i.e., high net fractionations - are characteristic of systems where sulfate is less limiting, such as in the water column of the Black Sea today (Lyons, 1997). Anomalously high (strongly positive) $\delta^{34} \mathrm{~S}$ data, as described in this report, require strong limitations in sulfate availability on either a local or global scale.

\section{Sulfur Geochemical Records of Precambrian Ocean- Atmosphere Conditions-An Overview}

Relevant details of the Precambrian sulfur cycle are provided in a recent review paper by Lyons et al. (2004) and in the references cited within that synthesis. These details are also summarized schematically in Figure 2. Briefly, recent estimates by Shen et al. (2001) place the onset of BSR at ca. $3.47 \mathrm{Ga}$ (billion years ago). Despite this possibility, extremely low seawater sulfate concentrations (likely less than $200 \mu \mathrm{M}$ ) throughout the Archean beneath an $\mathrm{O}_{2}$-deficient atmosphere yielded only local examples of the large $\mathrm{S}$ isotope fractionations that are often diagnostic of BSR (cf. Ohmoto et al., 1993, Kakegawa et al., 1998, and 
Kakegawa and Ohmoto, 1999). These exceptions might record local, evaporative enrichments in seawater sulfate. By ca. $2.3 \mathrm{Ga}$, sulfate concentrations within seawater increased to levels where fractionations of a few tens of per mil are commonly observed in bacteriogenic pyrite. This spread in the $\delta^{34} \mathrm{~S}$ data is coincident with the so-called Great Oxidation Event (Holland, 2002; Farquhar and Wing, 2003; Bekker et al., 2004), when redox conditions at Earth's surface are thought by most workers to have shifted fundamentally from reducing to oxidizing. At this time, weathering of sulfide minerals exposed on the continents beneath an $\mathrm{O}_{2}$-containing atmosphere would have led to appreciable increases in the flux of sulfate to the ocean (Fig. 2) - although oxygen concentrations were still only a small fraction of present atmospheric levels.

Although seawater sulfate concentrations rose in the early Proterozoic, its availability relative to the Phanerozoic ocean remained low throughout most if not all of the Proterozoic. Evidence for low sulfate concentrations - on the order of $<5 \%$ to $15 \%$ of the present-day value of 28-29 mM for the mid-Proterozoic - is seen in the abundance of ${ }^{34} \mathrm{~S}$-enriched pyrite deposited during this interval (Shen et al., 2002, 2003; this report) and in the rapid and large-magnitude $\mathrm{S}$ isotope variability observed stratigraphically in many Proterozoic sulfide- and sulfate-bearing sedimentary sequences (Luepke and Lyons, 2001; Hurtgen et al., 2002, 2004; Kah et al., 2004; Gellatly and Lyons, 2005). During the Phanerozoic, by contrast, $\delta^{34} \mathrm{~S}$ fluctuations of similar magnitude are described by Claypool et al. (1980) for time periods of $10^{7}$ to $10^{8}$ years. By the late Proterozoic, atmospheric oxygen levels rose sufficiently-with a corresponding rise in oceanic sulfate - to support increases in $\mathrm{S}$ isotope fractionations between sulfate and sulfide to values typical of the Phanerozoic (i.e., up to and exceeding 60\%o). Canfield and Teske (1996) attributed this increased fractionation to evolution among non-photosynthetic sulfide-oxidizing bacteria, which accelerated the production of intermediate $\mathrm{S}$ species and thus the disproportionation reactions that can magnify the net isotope effect. However, overall increases in sulfate concentration would also have supported larger net fractionations, and a persistence of rapid $\delta^{34} \mathrm{~S}$ variability in the marine sulfate reservoir would make fractionations between coeval sulfate and sulfide difficult to evaluate (Lyons et al., 2004; Hurtgen et al., 2005).

The Archean is generally regarded as a time of low oxygen and sulfate availability in the ocean. Under these conditions, high concentrations of dissolved iron supported extensive deposition of banded iron formations (BIFs). Across the Great Oxidation
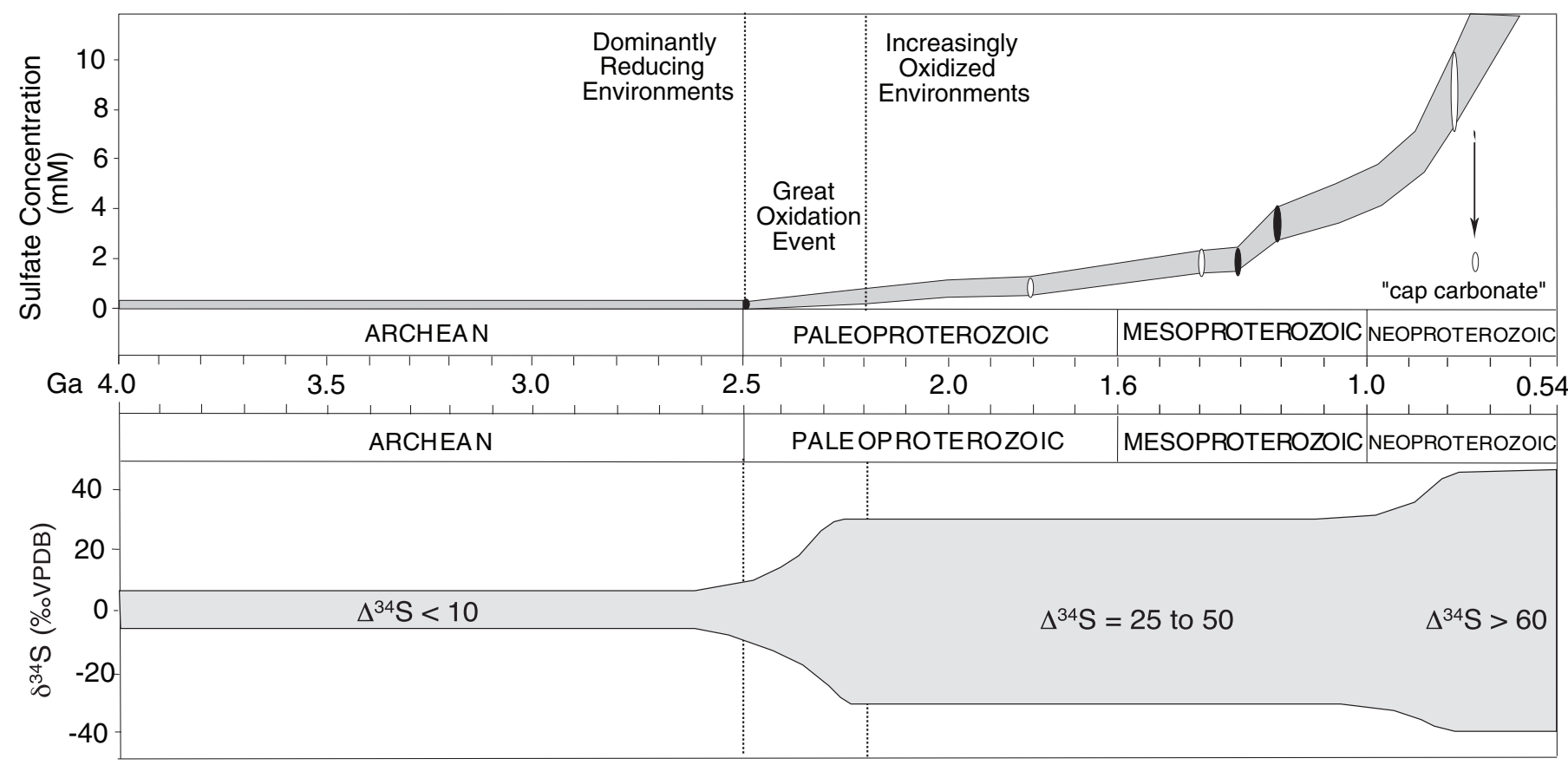

Figure 2. Estimates of sulfate concentration and a schematic of $\delta^{34} \mathrm{~S}$ values for bacteriogenic pyrite from the Archean and Proterozoic. Proterozoic sulfate concentrations are based on the Kah et al. (2004) model for S isotope variability as recorded in CAS. Archean estimates reflect the low sulfate values required to explain the predominance of small bacterial $\mathrm{S}$ isotope fractionations observed during this interval (Habicht et al., 2002). The pyrite $\delta^{34} \mathrm{~S}$ schematic (lower figure) is based on the compilation of Shen et al. (2001). Increasing fractionations between sulfate and sulfide $\left(\Delta^{34} \mathrm{~S}\right)$ during BSR following the G.O.E. are inferred to record sulfate concentrations in the ocean that increased to values in excess of $\sim 200 \mu \mathrm{M}$. Canfield and Teske (1996) attributed the increase in $\Delta^{34} \mathrm{~S}$ in the Neoproterozoic to an increasing role by disproportionating bacteria in the sulfur cycle, although this interpretation has recently been challenged (Hurtgen et al., 2005). Because most of the sulfate in the ocean derives from continental weathering of sulfide minerals beneath an $\mathrm{O}_{2}$-containing atmosphere, increasing sulfate concentrations in seawater track the oxygenation of the Proterozoic atmosphere. 
Event ca. $2.3 \mathrm{Ga}$, oxygen in the atmosphere and thus sulfate in the ocean increased to levels that supported widespread marine BSR. A recent model argues, however, that under the comparatively low oxygen conditions of the Proterozoic atmosphere, the deep ocean may have remained free of oxygen for more than a billion years beyond the oxidation event (Canfield, 1998). Canfield argued that within this anoxic environment, and in the presence of a growing oceanic sulfate reservoir, sulfate-reducing bacteria would have thrived-giving rise to euxinic conditions throughout much of the deep Proterozoic water column (also Anbar and Knoll, 2002). Recently, Mo isotope data from Proterozoic black shales have confirmed the possibility of widespread oxygen deficiency and perhaps euxinia in the Proterozoic ocean (Arnold et al., 2004). Such conditions may have persisted until the Neoproterozoic when a second major oxygenation of Earth's surface resulted in a widely oxic deep ocean and ultimately the appearance of multicellular organisms (Des Marais et al., 1992;
Canfield, 1998). Despite this fundamental shift, the redox transition in the marine realm was complicated by the possibility of persistent or renewed oxygen deficiency within the isolated, icecovered glacial ocean of the Neoproterozoic snowball Earth episodes (Hoffman et al., 1998; Hurtgen et al., 2002, 2004).

\section{SULFUR ISOTOPE TRENDS}

In an earlier study, Lyons et al. (2000) showed a preponderance of high $\delta^{34} \mathrm{~S}$ values in disseminated bacteriogenic pyrite extracted from organic-rich shales hosting the Sheep Creek and Soap Gulch SEDEX mineralization found within the ca. $1.47 \mathrm{Ga}$ lower Belt Supergroup. The massive pyrite within the mineralized intervals showed similar enrichments. On further examination, strong stratigraphic trends were observed within the host shales, with upsection $\delta^{34} \mathrm{~S}$ decreases of $\sim 45 \%$ and $12 \%$ over thicknesses of $45 \mathrm{~m}$ and $134 \mathrm{~m}$, respectively (Fig. 3). Subsequently,

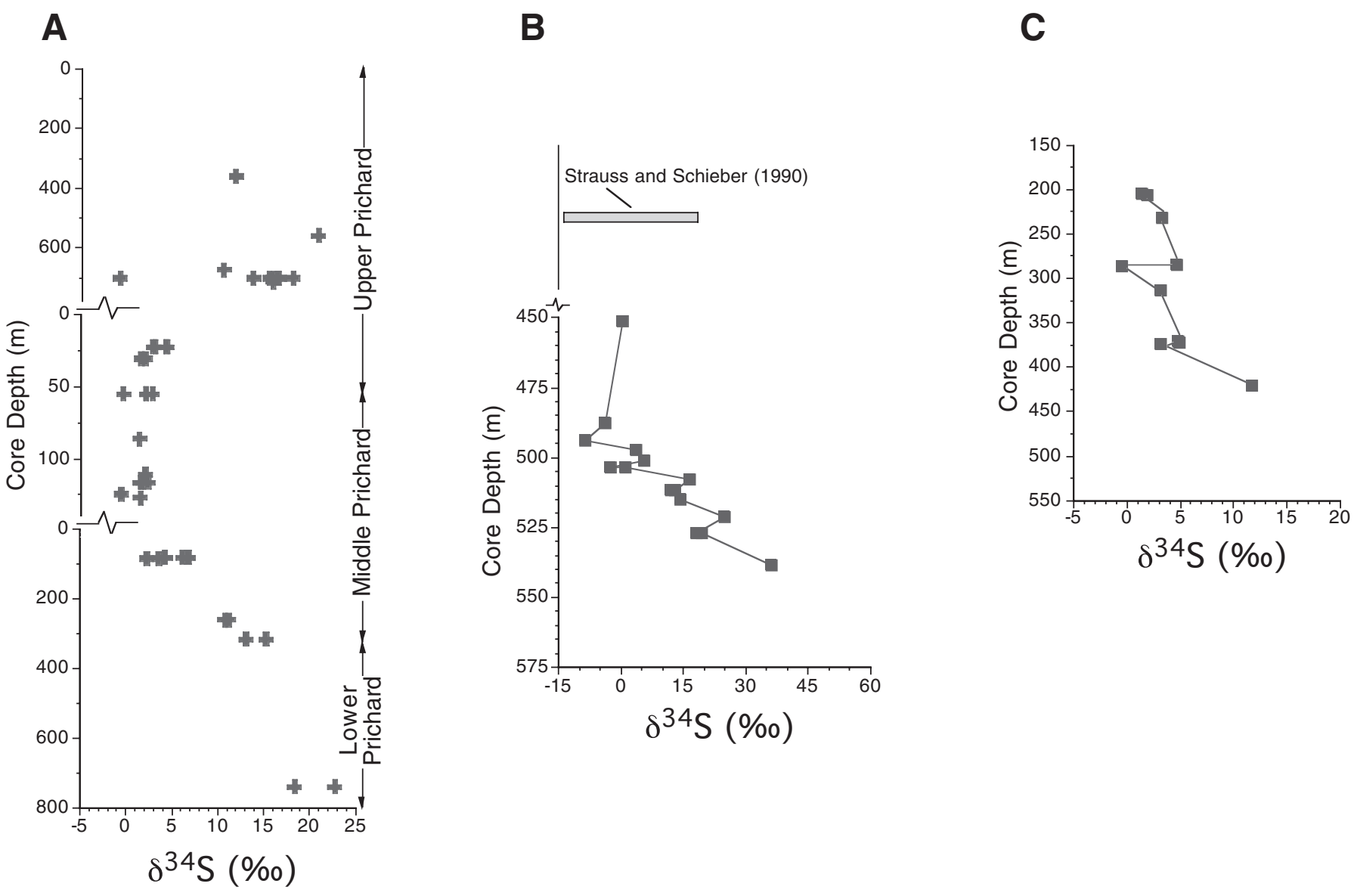

Figure 3. Stratigraphic distributions of $\delta^{34} \mathrm{~S}$ data for drill core samples of the (A) Prichard and (B and C) Newland Formations (ca. 1.47 Ga) of the Belt Supergroup, northwestern United States. Prichard data are from the "main" Belt Basin and represent fine-scale pyrite/pyrrhotite laminae, lenses, and disseminations within dark-gray to black argillites. The Newland data are from disseminated pyrite within black shales collected within the Helena Embayment - the easternmost extension of the Belt Basin. The Newland shales are host to massive, SEDEX-type sulfide mineralization in stratigraphic and spatial proximity to the data shown here. Nevertheless, the low-temperature, bacteriogenic pyrite in these shales and argillites appears to be unrelated to mineralizing, hydrothermal activity. Further details are available in Lyons et al. (2000) and Luepke and Lyons (2001). 
analogous patterns have been found in pyrite and pyrrhotite from the lower Belt Supergroup away from mineralized regions in metamorphosed argillitic equivalents. These data show both decreasing and increasing stratigraphic trends for $\delta^{34} \mathrm{~S}$ (Fig. 3) (Luepke and Lyons, 2001). Collectively, the isotopic data and the relationships between organic carbon and pyrite sulfur in these sediments were viewed as convincing evidence for marine inputs into the Mesoproterozoic Belt Basin. The extent of marine deposition within the Belt Supergroup has been debated for decades (Winston, 1990; Winston and Link, 1993).

The abundance of ${ }^{34} \mathrm{~S}$-enriched values in the lower Belt Supergroup was assumed to reflect marine inputs into a highly restricted setting that may have been shut off intermittently from the open ocean. At the time of initial publication, the stratigraphic trends reproduced in Figure 3 were viewed as evidence for temporal variation in the strength of the local marine connectionwith the lowest $\delta^{34} \mathrm{~S}$ values reflecting the most open conditions. In subsequent years, we have observed that large and often-systematic $\delta^{34} \mathrm{~S}$ variations over relatively short stratigraphic intervals within single sedimentary units are not unusual for Proterozoic sulfide accumulations (Ross et al., 1995; Strauss, 1997, 2002), including SEDEX mineralization (Carr and Smith, 1977; Smith et al., 1978; McGoldrick et al., 1999), and that these patterns may have global implications (Kah et al., 2004; Lyons et al., 2004).

The pronounced ${ }^{34} \mathrm{~S}$ enrichments that dominate the sulfides of the lower Belt Supergroup are also common throughout the Proterozoic record (Lambert and Donnelly, 1991; Logan et al., 1995; Canfield, 1998; Canfield and Raiswell, 1999; Gorjan et al., 2000; Shen et al., 2002, 2003; Strauss, 2002). Nowhere are these enrichments better expressed than in SEDEX mineralization. In Figure 4, we have compiled a large number of $\delta^{34} \mathrm{~S}$ data for SEDEX deposits spanning the Proterozoic. This compilation reflects a range of sulfide minerals, including ore-phase galena and sphalerite, as well as sedimentary sulfides (dominantly pyrite) in host sediments away from the hydrothermal mineralization. This selection of data is not intended to be a comprehensive survey of Proterozoic SEDEX ore deposits. Instead, we have tried to assemble a representative suite of the largest data sets, with an additional goal of providing broad temporal coverage. The most striking observations about Figure 4, and the focus of much of the discussion that follows, are the wide ranges of $\delta^{34} \mathrm{~S}$ values for each of the deposits and the predominance of ${ }^{34} \mathrm{~S}$ enrichments in the ore bodies and host shales.

\section{IMPLICATIONS}

\section{Stratigraphic Isotope Trends}

The patterns of comparatively rapid $\delta^{34} \mathrm{~S}$ variability described above for Proterozoic metal sulfides - that is, variations of tens of per mil over stratigraphic thicknesses of hundreds of meters or less - are also observed in samples of sulfate-S of Proterozoic age. These patterns have been observed both in gypsum (Fig. 5) (Kah et al., 2001, 2004) and carbonate-associated

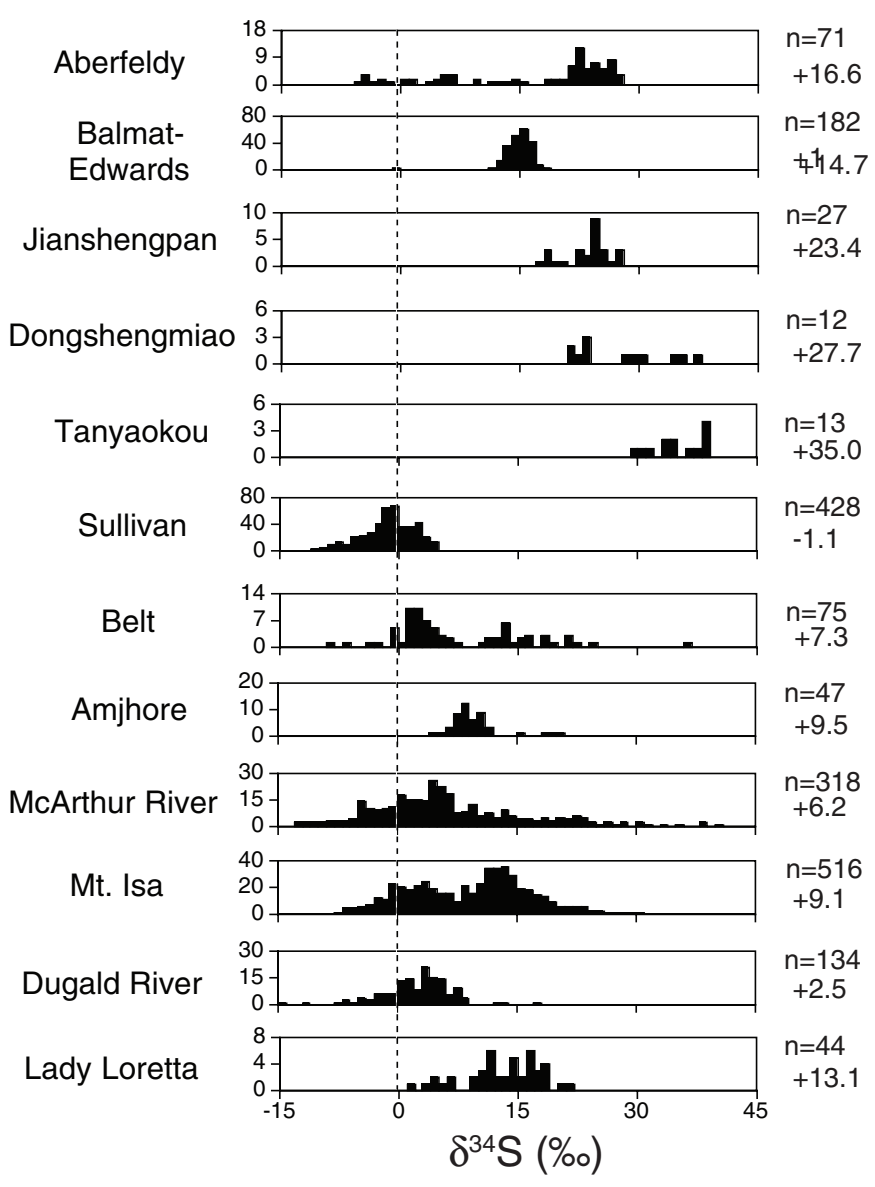

Figure 4. Summary of $\delta^{34} \mathrm{~S}$ data for sulfides from Proterozoic SEDEX deposits. Data represent pyrite and the full range of base metal sulfides present, as well as disseminated sulfides within the host sediments. References and location information are as follows: Aberfeldy, Scotland (Willan and Coleman, 1983); Balmat-Edwards, United States (Whelan et al., 1984); Jianshengpan, Dongshengmiao, and Tanyaokou, China (Ding and Jiang, 2000); Sullivan, Canada (Campbell et al., 1978, 1980); Belt Supergroup, United States (Lyons et al., 2000; Luepke and Lyons, 2001); Amjhore, India (Guha, 1971; Pandalai et al., 1991); McArthur River, Australia (Smith and Croxford, 1975; Rye and Williams, 1981; Eldridge et al., 1993; Shen et al., 2002); Mount Isa, Australia (Solomon, 1965; Smith et al., 1978; Andrew et al., 1989; Davidson and Dixon, 1992; Painter et al., 1999; McShane, 1996); Dugald River, Australia (Dixon and Davidson, 1996; Davidson and Dixon, 1992); Lady Loretta, Australia, (Carr and Smith, 1977; Scott et al., 1985). With the exception of the Chinese deposits, the histograms are stacked in a generally correct stratigraphic order. The Aberfeldy deposit is late Neoproterozoic. The Balmat-Edwards, Sullivan, Belt, and Amjhore deposits fall in a range of 1.3-1.5 Ga. McArthur River, Mount Isa, Dugald River, and Lady Loretta have ages of 1.6-1.7 Ga. Additional details about age relationships are available in Lyons et al. (2004) and in the primary references. We note the abundance of ${ }^{34} \mathrm{~S}$ enriched sulfides present in these deposits. By contrast, pyrite forming in the modern water columns of the Black Sea and Cariaco Basin have $\delta^{34} \mathrm{~S}$ values of $-30 \%$ o to $-40 \%$, with $\Delta^{34} \mathrm{~S}$ values of $\sim-50 \%$ o to $-60 \%$ o (Lyons, 1997; Lyons et al., 2003). 


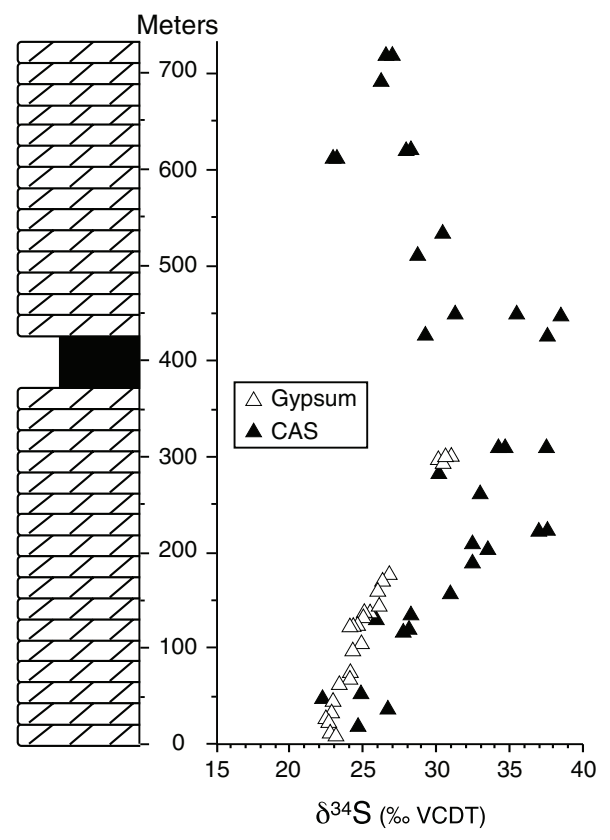

1.2 Ga Society Cliffs Formation

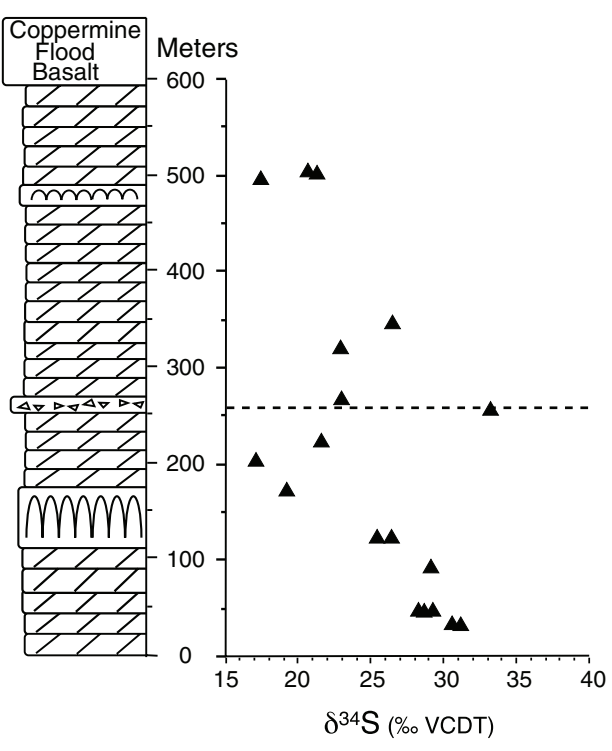

1.3 Ga Dismal Lakes Group
Figure 5. Left: Stratigraphic distribution of $\delta^{34} \mathrm{~S}$ data for massive, bedded gypsum and carbonate-associated sulfate (CAS) extracted from dolomite of the ca. 1.2 Ga Society Cliffs Formation, Bylot Supergroup, northeastern Arctic Canada. Right: CAS data from dolomite of the 1.3 Ga Dismal Lakes Group, north-central Arctic Canada (after Kah et al., 2001, 2004). sulfate (CAS) (Fig. 5) (Hurtgen et al., 2002, 2004; Kah et al., 2004; Gellatly and Lyons, 2005). In contrast to earlier arguments for local controls on the patterns observed in the Belt basin (Lyons et al., 2000; Luepke and Lyons, 2001), the spatially and temporally widespread nature of this style of isotopic variability now suggests a global control. Specifically, these $\delta^{34} S$ records preserved in sulfate and sulfide, including SEDEX deposits, may reflect rapid changes in the isotopic composition of seawater sulfate on a global scale. Such patterns of variability are unlike the temporally broad, first-order trend of the Claypool et al. (1980) sulfate curve, which has long defined the Phanerozoic paradigm for seawater isotopic behavior (also Strauss, 1997; Kampschulte and Strauss, 2004). Almost certainly the "Claypool paradigm" misrepresents the extent of short-term $\delta^{34} \mathrm{~S}$ variability recorded in younger rocks. We are exploring this possibility and see early signs of greater complexity in the Paleozoic record (Gill et al., 2006; also Kampschulte and Strauss, 2004), and marine barite is revealing the finer texture of $\delta^{34} \mathrm{~S}$ variability during the Mesozoic and Cenozoic (Paytan et al., 1998, 2004). Nevertheless, the shorter-term $\delta^{34} \mathrm{~S}$ shifts recorded in the barite data are smaller (on the order of 5\%o) and longer (roughly 5-10 m.y.) than those of the Proterozoic and likely the Paleozoic.

A Proterozoic ocean with appreciably lower sulfate concentrations, beneath an atmosphere with less oxygen, would be more vulnerable to rapid isotopic variability. A lower mass of sulfate in the ocean equates to a shorter residence time and thus higher sensitivity to $\delta^{34} \mathrm{~S}$ variation as driven by flux terms such as pyrite burial, weathering inputs, and volcanogenic sulfur. Kah et al. (2004) modeled the rate of $\delta^{34} \mathrm{~S}$ variability $\left(\mathrm{d} \delta^{34} \mathrm{~S} / \mathrm{dt}\right.$ ) observed at several Proterozoic localities, using both gypsum and CAS data, and estimated mid-Proterozoic seawater sulfate concentrations that were only $5 \%$ to $15 \%$ of present-day levels.

Previous sulfur workers have suggested that upsection increases in $\delta^{34} \mathrm{~S}$ observed over tens to hundreds of meters could, in general, reflect progressive sulfate depletions under closedsystem sulfate reduction - that is, isotopic evolution behaving as a Rayleigh distillation. This explanation is particularly attractive within the likely restricted, rifted tectonic settings that characterize most SEDEX deposits; however, it fails to explain the upsection decreases in $\delta^{34} \mathrm{~S}$ that are also observed. Furthermore, analogous trends have been observed in platform carbonate (CAS) and evaporite sequences, where local restriction and progressive ${ }^{34} \mathrm{~S}$ enrichment through local pyrite burial are difficult to imagine (Kah et al., 2001, 2004).

Mass balance calculations that weigh sulfate availability against total sulfide burial within shale hosts provide another important constraint (Fig. 6). The large amounts of metal sulfide within SEDEX deposits imply that a substantial fraction of the total basinal sulfate/sulfide reservoir is supplying sulfur to localized sites of enrichment. Consequently, sulfur supplied from single volumes of local pore water and the immediately overlying water column is typically not adequate to explain the large amount of ore sulfur present. In shales unaffected by SEDEX processes, however, we can explore stratigraphic isotopic trends in light of simple assumptions about the sulfur source-sink relationship. If pyrite in the shale is accumulating across the deep basin floor, and mechanisms are not in place for localized enrichment, we can estimate how much pyrite could be generated beneath a given parcel of seawater. We performed this calculation for a $1 \mathrm{~m} \times 1 \mathrm{~m}$ area of the water column, assuming closed system 


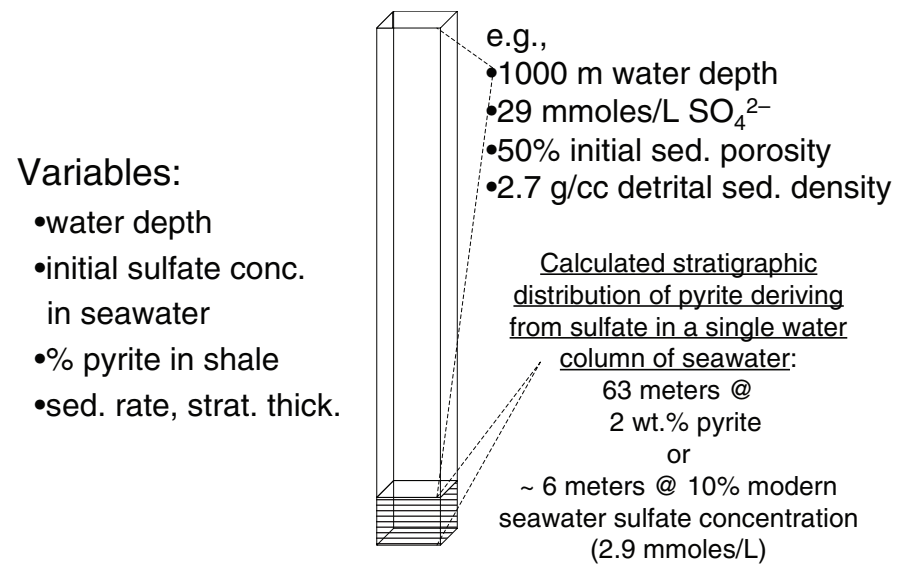

Figure 6. Simple mass balance calculation to assess maximum possible pyrite production from one basin-volume of seawater and specifically the pyrite's stratigraphic distribution in a shale host (unaffected by SEDEX mineralization) as predicted from concentrations in the final rock. Details are provided in the text.

behavior for that parcel and quantitative conversion of sulfate to $\mathrm{H}_{2} \mathrm{~S}$ and sequestration as $\mathrm{FeS}_{2}$ (Fig. 6). In other words, we are testing the oft-cited argument that systematic upsection increases in $\delta^{34} \mathrm{~S}$ within a black shale might reflect progressive evolution via BSR in a closed system.

Our simple model assumes that sufficient $\mathrm{Fe}$ is present to capture all of the sulfur in the system over the evolution of the closed system. In the example shown, water depth is assumed to be $1000 \mathrm{~m}$. Seawater sulfate concentration is chosen as today's value $(\sim 29 \mathrm{mM})$. The non-pyrite (detrital sediment) component is assumed to have a density of $2.7 \mathrm{~g} / \mathrm{cc}$, and the detrital sediment is assigned an initial porosity of $50 \%$. In this example, all of the sulfide is precipitated as pyrite - other metal sulfides would modify the results only slightly — and the iron sulfide is assumed to precipitate in the original pore space.

Under these model conditions, the stratigraphic distribution of the pyrite resulting from a single water column of seawater can be calculated for any wt.\% pyrite in the final sampletaken as a reasonable black shale value of $2 \%$ in this example (Fig. 6) -yielding accumulation over a stratigraphic thickness of only $63 \mathrm{~m}$. This thickness is insufficient to explain the stratigraphic extents of many progressive ${ }^{34} \mathrm{~S}$ enrichments observed in the shale record (e.g., Fig. 3), and a shallower water column or lower original seawater sulfate concentration could reduce the stratigraphic estimates significantly. For example, our estimate of $\sim 10 \%$ modern sulfate concentrations for the mid-Proterozoic would reduce the thickness estimates by a factor of ten, thus adding further credibility to arguments for global rather than local controls on observed $\delta^{34} \mathrm{~S}$ trends in the shales.

If the estimates for low sulfate in the Proterozoic ocean are correct, the stratigraphic trends preserved within the metal sulfides of shales and ore deposits could be tracking global seawater sulfate values. Under conditions of local isolation, the effects of low oceanic sulfate availability would be exacerbated during sulfate reduction, leading to sulfide $\delta^{34} \mathrm{~S}$ data that would also track the oceanic trend with little net fractionation between the parent sulfate and product sulfide. We have shown that many of the sulfide data are ${ }^{34} \mathrm{~S}$ enriched and that their ranges overlap strongly with those for the sulfate. Rapid isotopic variability in the ocean, in combination with pyrite formation under conditions of limited local and global sulfate availability, would yield the $\delta^{34} \mathrm{~S}$ ranges summarized in Figure 4.

\section{Controls on ${ }^{34}$ S Enrichments}

Other workers have suggested that widespread ${ }^{34} \mathrm{~S}$ enrichments in sedimentary pyrite are attributable to comparatively low sulfate concentrations in the Proterozoic ocean. For example, Shen et al. (2002) estimated sulfate levels of $0.5-2.4 \mathrm{mM}$ based on a model for sulfide accumulation in the late Paleoproterozoic deep waters of the McArthur Basin of northern Australia. Shen et al. (2003), in a focused study of the Mesoproterozoic Roper Group of the McArthur Basin, invoked a sulfate minimum zonea hypothesized interval within a stratified Proterozoic water column characterized by exaggerated sulfate deficiencies - to explain pronounced ${ }^{34} \mathrm{~S}$ enrichments observed within those sediments. A Proterozoic sulfate minimum zone, as first suggested by Logan et al. (1995), could have exacerbated the already low sulfate concentrations in the ocean. Hurtgen et al. $(2002,2004)$ noted that ${ }^{34} \mathrm{~S}$ enrichments in pyrite and large and rapid $\delta^{34} \mathrm{~S}$ excursions recorded in CAS - specifically in response to the Neoproterozoic glacial episodes - could reflect a suppressed riverine sulfate flux, in combination with nearly complete sulfate reduction within an isolated, anoxic global ocean (cf. Shields et al., 2004). These "snowball Earth" patterns, although generally linked to the overall low sulfate concentrations of the Proterozoic, are a subset of the longer-term controls and patterns described here.

Smaller fractionations during bacterial cycling of $\mathrm{S}$ would also facilitate ${ }^{34} \mathrm{~S}$ enrichments in Proterozoic sulfides. Specifically, Canfield and Teske (1996), in a now debated model (e.g., Hurtgen et al., 2005), favored reduced fractionations prior to the Neoproterozoic - arguing that the enhanced ${ }^{34} \mathrm{~S}$ depletions during disproportionation reactions had minimal or no influence prior to further increases in Earth surface oxidation late in the Proterozoic (cf. Johnston et al., 2005). Regardless, Canfield and Raiswell (1999), Strauss (2002), Shen et al. (2003), and others have shown that fractionations at least as large as those possible by BSR alone, and thus light $\delta^{34} \mathrm{~S}$ values, are also observed during the mid-Proterozoic, which suggests sulfate concentrations of $>200 \mu \mathrm{M}$ (Habicht et al., 2002).

Some diagenetic models suggest that extreme ${ }^{34} \mathrm{~S}$ enrichments in sulfide analogous to those described here (e.g., Fig. 4) may require sulfate concentrations of less than $1 \mathrm{mM}$ (Habicht et al., 2002; see Canfield, 2004). Because most pyrite in marine systems forms early, in the surface sediments or in the water column, $\delta^{34} \mathrm{~S}$ values tend to be ${ }^{34} \mathrm{~S}$ depleted in Phanerozoic sediments. 
$\delta^{34} \mathrm{~S}$ values commonly range between $-20 \%$ and $-40 \%$ in many modern euxinic sediments and Phanerozoic black shales (Sageman and Lyons, 2003). For example, although the modern Black Sea is only weakly linked to the Mediterranean Sea, the balance between rates of net sulfate reduction and sulfate replenishment, in combination with pyrite that forms primarily in the water column, yields typical open-system, ${ }^{34} \mathrm{~S}$-depleted pyrite that is almost $60 \%$ lighter than the coeval seawater sulfate (Calvert et al., 1996; Lyons, 1997; Wilkin and Arthur, 2001).

The $1 \mathrm{mM}$ sulfate maximum is lower by roughly a factor of two than the mid-Proterozoic predictions summarized here (e.g., Kah et al., 2004). Although not a big difference, these results suggest that SEDEX deposits and Proterozoic sediments in general, through quantitative sulfate reduction and efficient hydrogen sulfide retention as metal sulfides, may exceed typical, more-recent early diagenetic environments in their ability to generate extreme ${ }^{34} \mathrm{~S}$ enrichments. In modern marine sediments, as much as $95 \%$ of hydrogen sulfide generated is reoxidized (Jørgensen et al., 1990), in part because of limited supplies of reactive iron (Canfield et al., 1992). Under lower sulfate/sulfide conditions, iron limitation becomes less of a factor, particularly if iron and other sulfide-reactive metals are available in great abundance - suggesting anomalously high burial efficiencies for Proterozoic $\mathrm{H}_{2} \mathrm{~S}$ (Hurtgen et al., 2005). Also, the very high sedimentation rates expected in the isolated rift settings and the lack of Proterozoic bioturbation, regardless of benthic $\mathrm{O}_{2}$ levels, would have a pronounced effect on sulfate transport, reactive carbon availability, and sulfide retention within the sediments and could enhance ${ }^{34} \mathrm{~S}$ enrichment (Hurtgen et al., 2005). Furthermore, rates of BSR associated with SEDEX mineralization may have been anomalously high.

\section{The Possible Role of Methane}

Reduced concentrations of sulfate in the early ocean would have favored the production and preservation of methane (Habicht et al., 2002). Sulfate-reducing bacteria compete with methanogens for metabolizable organic compounds, and anaerobic oxidation of methane (AOM) occurs through a consortium of microorganisms, with BSR playing a central role (Boetius et al., 2000). Also, methanogens are anaerobes, and methanotropic bacteria readily oxidize methane in the presence of oxygen. Conditions of low oxygen, in combination with limited sulfate availability, would support a methane-rich ocean-atmosphere system (Pavlov et al., 2000; Habicht et al., 2002), which may have persisted, albeit at a reduced level, throughout most of the Proterozoic (Pavlov et al., 2003). The possibility of high levels of atmospheric methane during the Precambrian was indirectly advanced through the paleosol study of Rye et al. (1995), which has been challenged recently by Ohmoto et al. (2004).

Although a connection to the Proterozoic sulfur geochemistry is highly speculative, we also note that the most extreme ${ }^{34} \mathrm{~S}$-enrichments found in modern marine sediments occur in association with high fluxes of methane. High fluxes of methane within sedimentary systems support AOM and thus anomalously high subsurface rates of BSR and comparatively high associated $\delta^{34} \mathrm{~S}$ values for hydrogen sulfide and pyrite (Aharon and $\mathrm{Fu}$, 2000, 2003; Arvidson et al., 2004; M. Formolo, 2006, personal commun.). It is interesting to note that pyrite $\delta^{34} \mathrm{~S}$ values as high as those found commonly in the Proterozoic are best developed today where subsurface, AOM-driven secondary sulfur is overprinting freshwater sediments (Jørgensen et al., 2004). Despite a lack of direct evidence, high methane availability may have supported high rates of Proterozoic BSR, which, in combination with lower overall sulfate concentrations, basin restriction, and strong hydrogen sulfide retention, would have favored high $\delta^{34} \mathrm{~S}$ values for the metal sulfides.

In modern deep-water, cold seep environments, bacterial mats of sulfide-oxidizing Beggiatoa are often abundant, reflecting the high levels of methane and associated BSR that typify the near-surface environment immediately below the mats (Larkin et al., 1994; Zhang et al., 2005). Such mats form today chemoautotrophically-deriving energy from oxidation of the copious sulfide formed during AOM. In addition to their abundances of pyrite, modern cold seep and gas hydrate localities are also known for enhanced, often extensive barite deposition (Dickens, 2001; Greinert et al., 2002; Torres et al., 2003).

Organic biomarkers consistent with sulfide-oxidizing bacteria were recently reported from inter-ore beds at the giant Proterozoic McArthur River Zn-Pb SEDEX deposit (Logan and Hinman, 2001), and a diverse microfossil assemblage is preserved in black chert nodules intimately associated with $\mathrm{Zn}-\mathrm{Pb}$ mineralization (Oehler and Logan, 1977). Additional petrographic evidence for a microbial role in sulfide formation in the Proterozoic deposits comes from a diversity of macro- and micro-textures in iron and base metal sulfides (McGoldrick, 1999). In particular, "crinklywavy" laminated pyrite beds, which are ubiquitous in the northern Australian deposits and the eastern Belt Basin, are interpreted as pyritized microbial mats (Schieber, 1986, 1990; McGoldrick, 1999; McGoldrick et al., 1999) (Fig. 7).

\section{Other Evidence for Low Proterozoic Sulfate}

Low sulfate concentrations in the Proterozoic ocean are further suggested by other independent evidence: (1) a comparative scarcity of massive bedded gypsum deposits prior to the mid to late Proterozoic (Kah et al., 2004); (2) the generally lower amounts of barite associated with Proterozoic SEDEX deposits relative to Phanerozoic examples (Lydon, 1996) - although barium availability also plays an important role (Cooke et al., 2000); (3) possibly the low CAS concentrations in Proterozoic carbonates (Hurtgen et al., 2002, 2004; Pavlov et al., 2003; Gellatly and Lyons, 2005); and (4) perhaps even the widespread occurrence of dolomite in Precambrian rocks compared to younger sediments. Finally, carbon-sulfur relationships summarized in Strauss (2002) suggest marine deposition during the Paleo- and Mesoproterozoic that was characterized by lower concentrations of seawater sulfate than in the latest Precambrian and Phanerozoic. Lyons et 

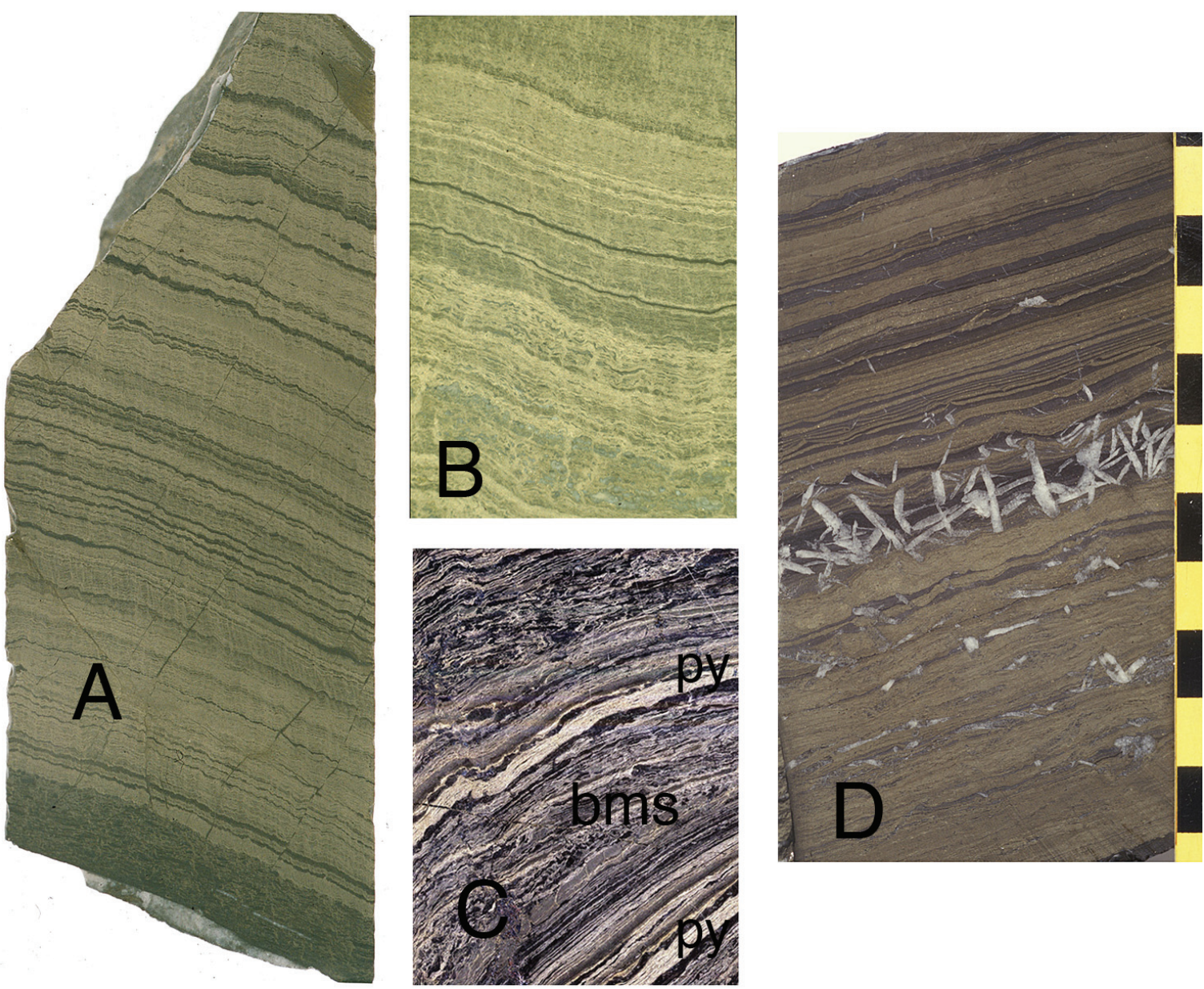

Figure 7. Core photos showing microbial mat-like textures preserved in pyrite and base metal sulfide ore from SEDEX deposits (Schieber, 1990; McGoldrick, 1999). (A) Unpolished slabbed core showing crinkly laminations in bedded pyrite from the late Paleoproterozoic Lady Loretta $\mathrm{Zn}-\mathrm{Pb}-\mathrm{Ag}$ deposit, northwest Queensland (width of core is $\sim 45 \mathrm{~mm}$ ). (B) Polished slabbed core from late Paleoproterozoic Grevillea $\mathrm{Zn}-\mathrm{Pb}-\mathrm{Ag}$ prospect (northwest Queensland) with crinkly laminated pyrite (width of sample $\sim 20 \mathrm{~mm}$ ). (C) Polished slabbed core of laminated high-grade $\mathrm{Zn}-\mathrm{Pb}$ sulfide ore from the Lady Loretta deposit (width of sample $\sim 20 \mathrm{~mm}$ ); note two prominent crinkly laminated pyrite bands (py) and partly disrupted laminated base metal sulfide and pyrite domains (bms). (D) slabbed core from the Mesoproterozoic Sheep Creek Cu-Co, Montana (width of sample $\sim 55 \mathrm{~mm}$ ); note compactional draping of pyrite laminae around early-formed barite laths.

al. (2000) described analogous high $\mathrm{C} / \mathrm{S}$ ratios for the shales of the lower Belt Supergroup (cf. Hurtgen et al., 2005).

\section{Paleoredox}

Proterozoic seawater sulfate concentrations, while low, were at least a factor of ten higher than those present during the Archean, as would be expected with the increased oxidation at Earth's surface beginning ca. 2.3 Ga. This extreme sulfur limitation alone may explain the absence of Archean SEDEX mineral deposits. Nonetheless, despite this fundamental shift in redox (Holland, 2002; Farquhar and Wing, 2003; Bekker et al., 2004), a growing body of evidence is suggesting that oxygen deficiency may have persisted in the deep ocean for as long as 1.5 b.y. following the Great Oxidation Event. Canfield (1998) first predicted this from a simple model that required only estimates of oxygen concentrations in the Proterozoic atmosphere and respiratory oxygen demand in the ocean-but without direct evidence. He further suggested that despite the relatively low sulfate conditions, the combination of a growing marine sulfate reservoir in the presence of deep-water anoxia may have led to widespread BSR and thus ocean-scale euxinia. Subsequent to Canfield's initial prediction, Mesoproterozoic euxinia was shown by Shen et al. (2003), Poulton et al. (2004), and Brocks et al. (2005) to have occurred at least on the scale of an individual basin and perhaps more generally throughout the ocean (Arnold et al., 2004).

Canfield (1998) extrapolated his model predictions for euxinia to suggest that BIFs may have disappeared ca. $1.8 \mathrm{Ga}$ not because of comprehensive oxygenation of the ocean but rather through a buildup of $\mathrm{H}_{2} \mathrm{~S}$ in the water column, which would have 
modulated Fe solubility through pyrite formation. As such, the $1.8 \mathrm{Ga}$ threshold would represent the time when increasing sulfur availability overcame the Fe fluxes to the ocean, including hydrothermal inputs (Isley and Abbott, 1999; Abbott and Isley, 2001; cf. Lowell and Keller, 2003). Consequently, it may not be fortuitous that SEDEX deposits first appear roughly when BIFs disappear - with both phenomena marking the generally widespread availability of $\mathrm{H}_{2} \mathrm{~S}$. Also of relevance, Condie et al. (2001) argued for a prominent maximum in Precambrian black shale deposition during a window from 2000 to $1700 \mathrm{Ma}$, which they linked at least partially to superplume activity.

An additional and essential benefit of widespread anoxia is the enhanced preservation of sulfide minerals residing on or near the seafloor. It is well known that sulfides deposited on the seafloor today along mid-ocean ridges are rapidly oxidized off axis beneath the oxic water column (Alt et al., 1989; Alt, 1994; Edwards et al., 2003).

\section{Paleotectonics and the Importance of Local Controls}

Although tectonic conditions must also be favorable for the production of hydrothermal, mineralizing fluids, high levels of rift-related heat flow are certainly not unique to the sites and time windows of SEDEX ore deposition. Intracratonic and continental margin, fault-controlled basins and troughs are common in rift zones throughout geologic history, and patterns of rifting are often intimately related to supercontinent breakup. It may be relevant, however, that the mid-Proterozoic maximum in SEDEX mineralization coincides with a proposed peak in superplume activity and thus oceanic hydrothermal fluxes (Isley and Abbott, 1999; Condie et al., 2001; see also Barley and Groves, 1992). Isolated, rift basins may also have favored the development of local anoxia, although the importance of this is less clear for the Proterozoic deposits when deep-water oxygen deficiency may have been common. Finally, rift-associated hydrothermal activity and fault conduits for possible methane and other hydrocarbon migration would have been ideal for enhancing metal availability and perhaps hydrogen sulfide production. A close relationship between SEDEX-type mineralization and ancient hydrocarbon seeps or vents has been suggested by others (e.g., Johnson et al., 2004).

\section{Comparisons with Younger Deposits}

Temporal selectivity of SEDEX mineralization is, to some extent, biased by a few very large and well-studied deposits. Similarly, the number of SEDEX deposits for a given time interval may be less meaningful than the total mass of mineralization. Nevertheless, peak periods of SEDEX mineralization seem clear and include both Proterozoic and Paleozoic time intervals (Fig. 1) (Lydon, 1996). The most straightforward conclusion from this distribution is that the Proterozoic onset of large-scale SEDEX mineralization almost certainly coincides with the early to midProterozoic accumulation of sulfate and sulfide within the global ocean system. Although sulfate was increasing over this interval, the predominance of ${ }^{34} \mathrm{~S}$-enriched sulfides suggests that sulfate remained well below modern levels.

The biggest complication in an otherwise consistent story is that Phanerozoic deposits are also known for their ${ }^{34} \mathrm{~S}$ enrichments - for example, Red Dog, Rammelsberg, and the deposits of the Selwyn Basin, all of which are Paleozoic in age (Anger et al., 1966; Goodfellow, 1987; Eldridge et al., 1988; Jennings and King, 2002) (Fig. 8). Given this, it would be easy to de-emphasize the importance of global controls in favor of local parameters, such as rift-related basin restriction with associated anoxia and local sulfate deficiencies. Although the abundant barite associated with Paleozoic deposits suggests that sulfate was increasing in the ocean, our recent work (Gill et al., 2006) and the studies of Horita et al. (2002), Lowenstein et al. (2003), Brennan et al. (2004), and Canfield (2004) suggest that sulfate increased but remained low relative to the modern ocean well into the Paleo-

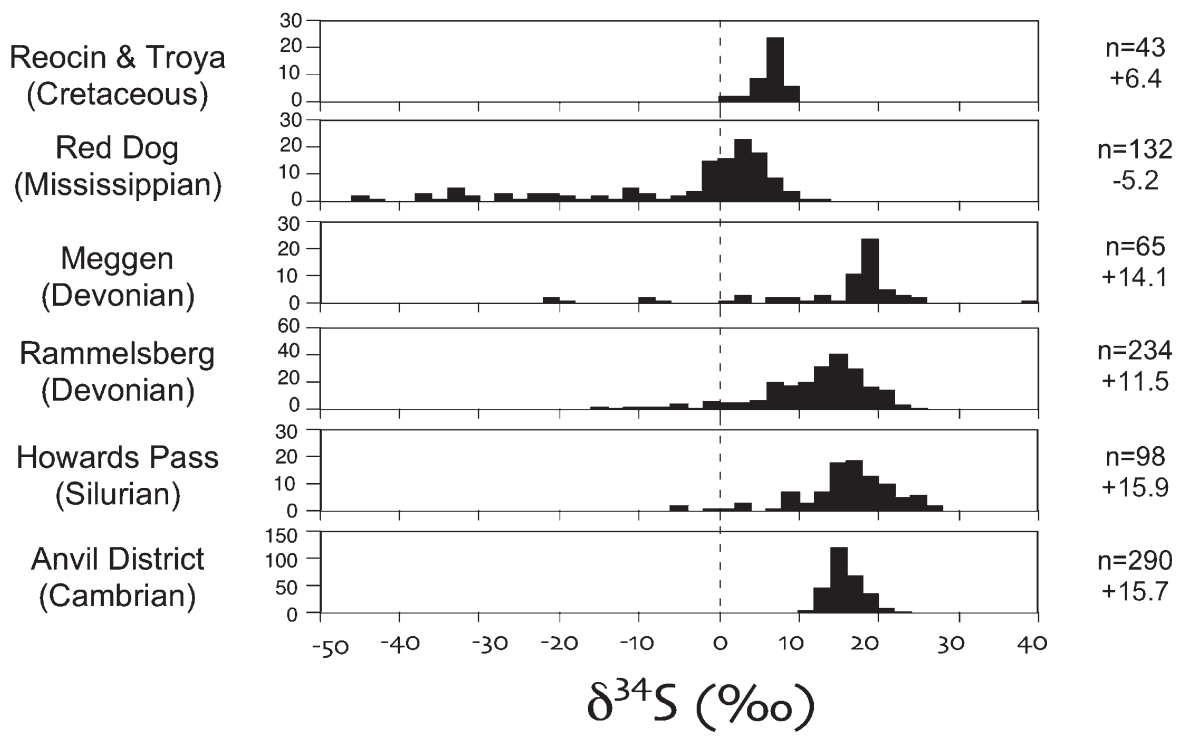

Figure 8. Summary of $\delta^{34} \mathrm{~S}$ data for selected Phanerozoic SEDEX deposits. Data represent pyrite and base metal sulfides. References and location information are as follows: Anvil District, Canada (Shanks et al., 1987); Howards Pass, Canada (Goodfellow and Jonasson, 1987); Rammelsberg, Germany (Anger et al., 1966); Meggen, Germany (Buschendorf et al., 1963); Red Dog, United States (Kelley et al., 2004); Reocin and Troya, Spain (Velasco et al., 1994). 
zoic. As for the Proterozoic, restricted, rift basin settings during the Phanerozoic would have intensified the conditions of comparatively low global oceanic sulfate availability.

The predominance of ${ }^{34} \mathrm{~S}$-enriched metal sulfides of Phanerozoic SEDEX deposits highlights even more clearly the necessity for high rates of BSR in combination with anomalously high efficiency in sulfide mineralization. Again, high, fault-controlled fluxes of methane and other hydrocarbons would drive high microbial production of hydrogen sulfide at or below the sediment-water interface, and associated hydrothermal activity would supply the metals necessary for sulfide mineralization. Most Phanerozoic SEDEX deposits are of the "Selwyn-type" (Cooke et al., 2000), and therefore the ore-forming fluids carried metals and reduced $\mathrm{S}$ together. Mixing this ore-fluid sulfide with sedimentary sulfide formed at the sites of ore deposition may produce $\mathrm{S}$ isotope patterns that are inherently more complex than those seen in "McArthur-type" deposits.

Mechanisms of SEDEX mineralization may intrinsically lead to strong local sulfate deficiencies and thus high ${ }^{34}$ S enrichments - regardless of the age. Zaback et al. (1993) and Jørgensen et al. (2004) remind us, however, that "closed-system" isotopic behavior often marks settings where sulfate resupply is occurring - but via fluxes that are overwhelmed by high rates of consumption by BSR. This model, for example, helps explain large amounts of ${ }^{34} \mathrm{~S}$-enriched sulfide, as are observed in SEDEX deposits, particularly if $\mathrm{H}_{2} \mathrm{~S}$ retention is high (Fig. 4). Today, such high rates of BSR are observed in association with AOM, particularly where other easily metabolized hydrocarbons are also released through seeps (Formolo et al., 2004). One could speculate that the fault control that is central to SEDEX mineralization plays a major role as a conduit for hydrocarbon migration in these organic-rich, shale-dominated settings.

The temporal and spatial distribution of Phanerozoic SEDEX mineralization almost certainly reflects the more strongly oxidizing conditions of the ocean, which would influence both $\mathrm{H}_{2} \mathrm{~S}$ availability and preservation of minerals precipitated at or near the seafloor. As a result, younger deposits may be limited to areas and episodes of basin-scale anoxia (Goodfellow and Jonasson, 1984; Turner, 1992), or they may have required an oxygen-shielding cap, either through barite deposition or mineralization below the sediment-water interface. The drop-off in abundance of Proterozoic deposits following the peak at $1800-1600 \mathrm{Ga}$ is more difficult to explain. Perhaps, in contrast to arguments for persistent euxinia, conditions were already too oxidizing to facilitate widespread bottom-water sulfide production and enhanced metal sulfide preservation. Proterozoic deposits are relatively lacking in barite, as would be expected given the comparatively low sulfate availability in the ocean. Thus, any protection from oxygen offered by a barite cap would be minimal.

\section{SUMMARY}

Our goal here was to explore the first-order temporal patterns observed for SEDEX mineralization in light of the most recent models for early ocean-atmosphere chemistry. Despite the many unanswered questions, a number of internally con- sistent, primary observations have emerged, which provide a framework for further exploring the origins and distributions of SEDEX mineralization:

1. The absence of volumetrically significant SEDEX mineralization during the Archean can be attributed to limitations in sulfide availability, which ultimately reflect seawater sulfate concentrations beneath an oxygen-deficient atmosphere that were perhaps less than $1 \%$ of those present today.

2. Following the fundamental shift to a more oxidizing atmosphere ca. $2.3 \mathrm{Ga}$, sulfate fluxes to the ocean increased significantly through continental weathering of sulfides exposed in the presence of oxygen. Despite increased atmospheric availability, oxygen may have remained scarce in the deep ocean for at least another billion years. This deep ocean condition was at least partially a consequence of atmospheric oxygen levels that remained far below those present today. Increasing sulfate combined with an $\mathrm{O}_{2}$-poor ocean could have spawned widespread euxinia throughout the Proterozoic ocean. The disappearance of banded iron formations ca. 1.8 Ga may mark the attainment of a critical threshold in $\mathrm{H}_{2} \mathrm{~S}$ accumulation in the ocean.

3. Given conditions that were tectonically favorable to hydrothermal sourcing of metals, the appearance of SEDEX mineralization ca. 1.8 Ga likely marks the ubiquity of $\mathrm{H}_{2} \mathrm{~S}$ in the marine system - including oxygen-deficient bottom waters - which favored the production and preservation of metal sulfide mineralization on the seafloor.

4. The common occurrence of ${ }^{34} \mathrm{~S}$ enrichments within SEDEX sulfides is viewed as a combined product of globally low seawater sulfate, high rates of bacterial sulfate reduction, and locally enhanced sulfate limitations under the partially closed rifted marine basins in which SEDEX mineralization occurs. Limited sulfate availability may also be recorded in the lower amounts of barite associated with Proterozoic deposits.

5. Despite the possibility of a widely sulfidic deep ocean, the high rates of sulfate reduction expressed in the ${ }^{34} \mathrm{~S}$ enrichments must, to an appreciable extent, reflect local bacterial activity. Enhanced local hydrocarbon fluxes and/or globally pervasive methane could have supported these high rates.

6. Following a mid-Proterozoic peak in SEDEX mineralization, the generally waning occurrence of these deposits throughout the latter part of the Proterozoic and only intermittent Phanerozoic occurrences may reflect increasing oxygenation of deep seawater and corresponding decreases in ambient $\mathrm{H}_{2} \mathrm{~S}$. Under these conditions, basins with restricted circulation and local bottom-water anoxia become increasingly important.

7. Paleozoic SEDEX sulfides commonly bear ${ }^{34} \mathrm{~S}$ enrichments analogous to those observed in the Proterozoic. The enrichments are partially a product of the local 
reservoir properties - specifically inhibited seawater/sulfate exchange with the open ocean. However, as for the Proterozoic, lower global seawater sulfate availability relative to today and high rates of bacterial sulfate reduction are suggested. It is an oversimplification to imagine that restricted marine conditions a priori favor extreme sulfate limitations. For example, Paleozoic deposits show large amounts of associated barite. Furthermore, purely closed system behavior is inconsistent with large amounts of metal sulfide formation. Instead, we emphasize the importance of anomalously high rates of bacterial reduction and $\mathrm{H}_{2} \mathrm{~S}$ retention under conditions of limited but not isolated sulfate supply.

\section{ACKNOWLEDGMENTS}

Support for this project was provided by NSF grants EAR9596079 and EAR-9725538 (Lyons and Kah). The authors benefited from many conversations with A. Anbar, D. Canfield, M. Hurtgen, and J. Luepke. D. Winston and G. Zieg are thanked for introducing the authors to the rocks of the Belt Supergroup. Research into the Proterozoic $\mathrm{Zn}-\mathrm{Pb}-\mathrm{Ag}$ deposits of northern Australia has been supported by grants from the Australian Research Council (ARC) and Australian Mineral Industry Research Association (AMIRA) to McGoldrick. Frank Corsetti and Barry Maynard provided insightful reviews, and we thank Steve Kesler and Hiroshi Ohmoto for their many efforts in assembling this volume.

\section{REFERENCES CITED}

Abbott, D., and Isley, A., 2001, Oceanic upwelling and mantle-plume activity: Paleomagnetic tests of ideas on the source of the Fe in early Precambrian iron formations, in Ernst, R.E., and Buchan, K.L., eds., Mantle plumes: Their identification through time: Geological Society of America Special Paper 352, p. 323-339.

Aharon, P., and Fu, B., 2000, Microbial sulfate reduction rates and sulfur and oxygen isotope fractionations at oil and gas seeps in deepwater Gulf of Mexico: Geochimica et Cosmochimica Acta, v. 64, p. 233-246, doi: 10.1016/S0016-7037(99)00292-6.

Aharon, P., and Fu, B., 2003, Sulfur and oxygen isotopes of coeval sulfate-sulfide in pore fluids of cold seep sediments with sharp redox gradients: Chemical Geology, v. 195, p. 201-218, doi: 10.1016/S0009-2541(02)00395-9.

Alt, J.C., 1994, A sulfur isotopic profile through the Troodos ophiolite, Cyprus: Primary composition and the effects of seawater hydrothermal alteration: Geochimica et Cosmochimica Acta, v. 58, p. 1825-1840, doi: 10.1016/0016-7037(94)90539-8.

Alt, J.C., Anderson, T.F., and Bonnell, L., 1989, The geochemistry of sulfur in a $1.3 \mathrm{~km}$ section of hydrothermally altered oceanic crust, DSDP Hole 504B: Geochimica et Cosmochimica Acta, v. 53, p. 1011-1023, doi: 10.1016/0016-7037(89)90206-8.

Anbar, A.D., and Knoll, A.H., 2002, Proterozoic ocean chemistry and evolution: A bioinorganic bridge?: Science, v. 297, p. 1137-1142, doi: 10.1126/ science. 1069651.

Andrew, A.S., Heinrich, C.A., Wilkins, R.W.T., and Patterson, D.J., 1989, Sulfur isotope systematics of copper ore formation at Mount Isa, Australia: Economic Geology and the Bulletin of the Society of Economic Geologists, v. 84, p. 1614-1626.

Anger, G., Nielsen, H., Puchelt, H., and Ricke, W., 1966, Sulfur isotopes in the Rammelsberg ore deposit (Germany): Economic Geology and the Bulletin of the Society of Economic Geologists, v. 61, p. 511-536.
Arnold, G.L., Anbar, A.D., Barling, J., and Lyons, T.W., 2004, Molybdenum isotope evidence for widespread anoxia in mid-Proterozoic oceans: Science, v. 304, p. 87-90, doi: 10.1126/science.1091785.

Arvidson, R.S., Morse, J.W., and Joye, S.B., 2004, The sulfur biogeochemistry of chemosynthetic cold seep communities, Gulf of Mexico, U.S.A: Marine Chemistry, v. 87, p. 97-119, doi: 10.1016/j.marchem.2003.11.004.

Barley, M.E., and Groves, D.I., 1992, Supercontinent cycles and the distribution of metal deposits through time: Geology, v. 20, p. 291-294, doi: 10.1130/0091-7613(1992)020<0291:SCATDO>2.3.CO;2.

Bekker, A., Holland, H.D., Wang, P.-L., Rumble, D., III, Stein, H.J., Hannah, J.L., Coetzee, L.L., and Beukes, N.J., 2004, Dating the rise of atmospheric oxygen: Nature, v. 427, p. 117-120, doi: 10.1038/nature02260.

Boetius, A., Ravenschlag, K., Schubert, C.J., Rickert, D., Widdel, F., Gieseke, A., Amann, R., Jørgensen, B.B., Witte, U., and Pfannkuche, O., 2000, A methane microbial consortium apparently mediating anaerobic oxidation of methane: Nature, v. 407, p. 623-626, doi: 10.1038/35036572.

Brennan, S.T., Lowenstein, T.K., and Horita, J., 2004, Seawater chemistry and the advent of biocalcification: Geology, v. 32, p. 473-476, doi: 10.1130/ G20251.1.

Brocks, J.J., Love, G.D., Summons, R.E., Knoll, A.H., Logan, G.A., and Bowden, S.A., 2005, Biomarker evidence for green and purple sulphur bacteria in a stratified Palaeoproterozoic sea: Nature, v. 437, p. 866-870.

Brunner, B., and Bernasconi, S.M., 2005, A revised isotope fractionation model for dissimilatory sulfate reduction in sulfate reducing bacteria: Geochimica et Cosmochimica Acta, v. 69, p. 4759-4771.

Buschendorf, Fr., Nielsen, H., Puchelt, H., and Ricke, W., 1963, Schwefelisotopen-untersuchungen am pyrit-sphalerit-baryt-lager Meggen/Lenne (Deutschland) und an verschiedenen Devon-evaporiten: Geochimica et Cosmochimica Acta, v. 27, p. 501-523.

Calvert, S.E., Thode, H.D., Yeung, D., and Karlin, R.E., 1996, A stable isotope study of pyrite formation in the Late Pleistocene and Holocene sediments of the Black Sea: Geochimica et Cosmochimica Acta, v. 60, p. 12611270, doi: 10.1016/0016-7037(96)00020-8.

Campbell, F.A., Ethier, V.G., Krouse, H.R., and Both, R.A., 1978, Isotopic composition of sulfur in the Sullivan orebody, British Columbia: Economic Geology and the Bulletin of the Society of Economic Geologists, v. 73, p. 246-268.

Campbell, F.A., Ethier, V.G., and Krouse, H.R., 1980, The massive sulfide zone; Sullivan orebody: Economic Geology and the Bulletin of the Society of Economic Geologists, v. 75, p. 916-926.

Canfield, D.E., 1998, A new model for Proterozoic ocean chemistry: Nature, v. 396 , p. $450-453$, doi: $10.1038 / 24839$

Canfield, D.E., 2001, Isotope fractionation by natural populations of sulfatereducing bacteria: Geochimica et Cosmochimica Acta, v. 65, p. 1117 1124, doi: 10.1016/S0016-7037(00)00584-6.

Canfield, D.E., 2004, The evolution of the Earth surface sulfur reservoir: American Journal of Science, v. 304, p. 839-861.

Canfield, D.E., and Raiswell, R., 1999, The evolution of the sulfur cycle: American Journal of Science, v. 299, p. 697-723.

Canfield, D.E., and Teske, A., 1996, Late Proterozoic rise in atmospheric oxygen concentration inferred from phylogenetic and sulphur-isotope studies: Nature, v. 382, p. 127-132, doi: 10.1038/382127a0.

Canfield, D.E., and Thamdrup, B., 1994, The production of ${ }^{34}$ S-depleted sulfide during bacterial disproportionation of elemental sulfur: Science, v. 266, p. 1973-1975.

Canfield, D.E., Raiswell, R., and Bottrell, S., 1992, The reactivity of sedimentary iron minerals toward sulfide: American Journal of Science, v. 292, p. 659-683.

Carr, G.R., and Smith, J.W., 1977, A comparative isotopic study of the Lady Loretta zinc-lead-silver deposit: Mineralium Deposita, v. 12, p. 105-110, doi: 10.1007/BF00204509.

Chambers, L.A., Trudinger, P.A., Smith, J.W., and Burns, M.S., 1975, Fractionation of sulfur isotopes by continuous cultures of Desulfovibrio desulfuricans: Canadian Journal of Microbiology, v. 21, p. 1602-1607.

Claypool, G.E., Holser, W.T., Kaplan, I.R., Sakai, H., and Zak, I., 1980, The age curves of sulfur and oxygen isotopes in marine sulfate and their mutual interpretations: Chemical Geology, v. 28, p. 199-260, doi: 10.1016/00092541(80)90047-9.

Condie, K.C., Des Marais, D.J., and Abbott, D., 2001, Precambrian superplumes and supercontinents: A record in black shales, carbon isotopes, and paleoclimates?: Precambrian Research, v. 106, p. 239-260, doi: 10.1016/S0301-9268(00)00097-8. 
Cooke, D.R., Bull, S.W., Large, R.R., and McGoldrick, P.J., 2000, The importance of oxidized brines for the formation of Australian Proterozoic stratiform sediment-hosted $\mathrm{Pb}-\mathrm{Zn}$ (Sedex) deposits: Economic Geology and the Bulletin of the Society of Economic Geologists, v. 95, p. 1-17.

Davidson, G.J., and Dixon, G.H., 1992, Two sulphur isotope provinces deduced from ores in the Mount Isa eastern succession, Australia: Mineralium Deposita, v. 27, p. 30-41, doi: 10.1007/BF00196078.

Des Marais, D.J., Strauss, H., Summons, R.E., and Hayes, J.M., 1992, Carbon isotope evidence for the stepwise oxidation of the Proterozoic environment: Nature, v. 359, p. 605-609, doi: 10.1038/359605a0.

Detmers, J., Brüchert, V., Habicht, K.S., and Kuever, J., 2001, Diversity of sulfur isotope fractionations by sulfate-reducing prokaryotes: Applied and Environmental Microbiology, v. 67, p. 888-894, doi: 10.1128/ AEM.67.2.888-894.2001.

Dickens, G.R., 2001, Sulfate profiles and barium fronts in sediment on the Blake Ridge: Present and past methane fluxes through a large gas hydrate reservoir: Geochimica et Cosmochimica Acta, v. 65, p. 529-543, doi: 10.1016/S0016-7037(00)00556-1.

Ding, T.-P., and Jiang, S.-Y., 2000, Stable isotope study of the Langshan polymetallic mineral district, Inner Mongolia, China: Resource Geology, v. 50, p. $25-38$.

Dixon, G.H., and Davidson, G.J., 1996, Stable isotope evidence for thermochemical sulfate reduction in the Dugald River (Australia) strata-bound shale-hosted zinc-lead deposit: Chemical Geology, v. 129, p. 227-246, doi: 10.1016/0009-2541(95)00177-8.

Edwards, K.J., McCollom, T.M., Konishi, H., and Buseck, P.R., 2003, Seafloor bioalteration of sulfide minerals: Results from in situ incubation studies: Geochimica et Cosmochimica Acta, v. 67, p. 2843-2856, doi: 10.1016/ S0016-7037(03)00089-9.

Eldridge, C.S., Compston, W., Williams, I.S., Both, R.A., Walshe, J.L., and Ohmoto, H., 1988, Sulfur isotope variability in sediment-hosted massive sulfide deposits as determined using the ion microprobe SHRIMP: I. An example from the Rammelsberg orebody: Economic Geology and the Bulletin of the Society of Economic Geologists, v. 83, p. 443-449.

Eldridge, C.S., Williams, N., and Walshe, J.L., 1993, Sulfur isotope variability in sediment-hosted massive sulfide deposits as determined using the ion microprobe SHRIMP: II. A study of the H.Y.C. Deposit at McArthur River, Northern Territory, Australia: Economic Geology and the Bulletin of the Society of Economic Geologists, v. 88, p. 1-26.

Farquhar, J., and Wing, B.A., 2003, Multiple sulfur isotopes and the evolution of the atmosphere: Earth and Planetary Science Letters, v. 213, p. 1-13, doi: 10.1016/S0012-821X(03)00296-6.

Formolo, M.J., Lyons, T.W., Zhang, C., Kelley, C., Sassen, R., Horita, J., and Cole, D.R., 2004, Quantifying carbon sources in the formation of authigenic carbonates at gas hydrate sites in the Gulf of Mexico, v. 205, p. 253-264.

Gellatly, A.M., and Lyons, T.W., 2005, Trace sulfate in mid-Proterozoic carbonates and the sulfur isotope record of biospheric evolution: Geochimica et Cosmochimica Acta, v. 69, p. 3813-3829.

Gill, B.C., Lyons, T.W., and Saltzman, M.R., 2006, Parallel, high-resolution carbon and sulfur isotope records of the evolving Paleozoic marine sulfur reservoir: Palaeogeography, Palaeoclimatology, Palaeoecology (in press).

Goodfellow, W.D., 1987, Anoxic stratified oceans a source of sulphur is sediment-hosted stratiform $\mathrm{Zn}-\mathrm{Pb}$ deposits (Selwyn Basin, Yukon, Canada): Chemical Geology, v. 65, p. 359-382.

Goodfellow, W.D., and Jonasson, I.R., 1984, Ocean stagnation and ventilation defined by $\delta^{34} \mathrm{~S}$ secular trends in pyrite and barite, Selwyn Basin, Yukon: Geology, v. 12 , p. 583-586, doi: 10.1130/0091-7613(1984)12<583: OSAVDB $>2.0 . C O ; 2$.

Goodfellow, W.D., and Jonasson, I.R., 1987, Environment of formation of the Howards Pass (XY) Zn-Pb deposit, Selwyn Basin, Yukon, in Morin, J.A., ed., Mineral deposits of Northern Cordillera: Canadian Institute of Mining and Metallurgy, Special Volume 37, p. 19-50.

Goodfellow, W.D., Lydon, J.W., and Turner, R.J.W., 1993, Geology and genesis of stratiform sediment-hosted (SEDEX) zinc-lead-silver sulphide deposits: Geological Association of Canada Special Paper 40, p. 201-251.

Gorjan, P., Veevers, J.J., and Walter, M.R., 2000, Neoproterozoic sulfur-isotope variation in Australia and global implications: Precambrian Research, v. 100, p. 151-179, doi: 10.1016/S0301-9268(99)00073-X.

Greinert, J., Bollwerk, S.M., Derkachev, A., Bohrmann, G., and Suess, E., 2002, Massive barite deposits and carbonate mineralization in the Derugin Basin, Sea of Okhotsk: Precipitation processes at cold seep sites: Earth and Planetary Science Letters, v. 203, p. 165-180, doi: 10.1016/ S0012-821X(02)00830-0.
Guha, J., 1971, Sulfur isotope study of the pyrite deposit of Amjhore, Shahbad District, Bihar, India: Economic Geology and the Bulletin of the Society of Economic Geologists, v. 66, p. 326-330.

Habicht, K.S., and Canfield, D.E., 2001, Isotope fractionation by sulfatereducing natural populations and the isotopic composition of sulfide in marine sediments: Geology, v. 29, p. 555-558, doi: 10.1130/00917613(2001)029<0555:IFBSRN $>2.0$. CO;2.

Habicht, K.S., Gade, M., Thamdrup, B., Berg, P., and Canfield, D., 2002, Calibration of sulfate levels in the Archean Ocean: Science, v. 298, p. 2372 2374, doi: $10.1126 /$ science. 1078265 .

Hoffman, P.F., Kaufman, A.J., Halverson, G.P., and Schrag, D.P., 1998, A Neoproterozoic snowball Earth: Science, v. 281, p. 1342-1346, doi: 10.1126/ science.281.5381.1342.

Holland, H.D., 2002, Volcanic gases, black smokers, and the Great Oxidation Event: Geochimica et Cosmochimica Acta, v. 66, p. 3811-3826, doi: 10.1016/S0016-7037(02)00950-X.

Horita, J., Zimmermann, H., and Holland, H.D., 2002, Chemical evolution of seawater during the Phanerozoic: Implications from the record of marine evaporites: Geochimica et Cosmochimica Acta, v. 66, p. 3733-3756, doi: 10.1016/S0016-7037(01)00884-5

Hurtgen, M.T., Arthur, M.A., and Halverson, G.P., 2005, Neoproterozoic sulfur isotopes, the evolution of microbial sulfur species, and the burial efficiency of sulfide as sedimentary pyrite: Geology, v. 33, p. 41-44, doi: 10.1130/G20923.1.

Hurtgen, M.T., Arthur, M.A., and Prave, A.R., 2004, The sulfur isotope composition of carbonate-associated sulfate in Mesoproterozoic to Neoproterozoic carbonates from Death Valley, California, in Amend, J.P., Edwards, K.J., and Lyons, T.W., eds., Sulfur biogeochemistryPast and present: Geological Society of America Special Paper 379, p. $177-194$.

Hurtgen, M.T., Arthur, M.A., Suits, N., and Kaufman, A.J., 2002, The sulfur isotopic composition of Neoproterozoic seawater sulfate: Implications for a snowball Earth?: Earth and Planetary Science Letters, v. 203, p. $413-$ 429, doi: 10.1016/S0012-821X(02)00804-X.

Isley, A.E., and Abbott, D.H., 1999, Plume-related mafic volcanism and the deposition of banded iron formation: Journal of Geophysical Research, v. 104, p. 15461-15477, doi: 10.1029/1999JB900066.

Jennings, S., and King, A.R., 2002, Geology, exploration history and future discoveries in the Red Dog district, western Brooks Range, Alaska, in Cooke, D., and Pongratz, J., eds., Giant ore deposits: Characteristics, genesis and exploration: Hobart, Australia, Centre for Ore Deposit Research, CODES Special Publication 4, p. 151-158

Johnson, C.A., Kelley, K.D., and Leach, D.L., 2004, Sulfur and oxygen isotopes in barite deposits of the western Brooks Range, Alaska, and implications for the origin of the Red Dog massive sulfide deposits: Economic Geology and the Bulletin of the Society of Economic Geologists, v. 99, p. $1435-1448$.

Johnston, D.T., Wing, B.A., Farquhar, J., Kaufman, A.J., Strauss, H., Lyons, T.W., Kah, L.C., and Canfield, D.E., 2005, Active microbial sulfur disproportionation in the Mesoproterozoic: Science, v. 310, p. 1477-1479.

Jørgensen, B.B., Bang, M., and Blackburn, T.H., 1990, Anaerobic mineralization in marine sediments from the Baltic Sea-North Sea transition: Marine Ecology Progress Series, v. 59, p. 39-54.

Jørgensen, B.B., Böttcher, M.E., Lüschen, H., Neretin, L.N., and Volkov, I.I., 2004, Anaerobic methane oxidation and a deep $\mathrm{H}_{2} \mathrm{~S}$ sink generate isotopically heavy sulfide in Black Sea sediments: Geochimica et Cosmochimica Acta, v. 68, p. 2095-2118, doi: 10.1016/j.gca.2003.07.017.

Kah, L.C., Lyons, T.W., and Chesley, J.T., 2001, Geochemistry of a $1.2 \mathrm{Ga}$ carbonate-evaporite succession, northern Baffin and Bylot islands: Implications for Mesoproterozoic marine evolution: Precambrian Research, v. 111, p. 203-234, doi: 10.1016/S0301-9268(01)00161-9.

Kah, L.C., Lyons, T.W., and Frank, T.D., 2004, Low marine sulphate and protracted oxygenation of the Proterozoic biosphere: Nature, v. 431, p. 834 838, doi: 10.1038 /nature 02974

Kakegawa, T., and Ohmoto, H., 1999, Sulfur isotope evidence for the origin of 3.4 to $3.1 \mathrm{Ga}$ pyrite at the Princeton gold mine, Barberton Greenstone Belt, South Africa: Precambrian Research, v. 96, p. 209-224, doi: 10.1016/S0301-9268(99)00006-6.

Kakegawa, T., Kawai, H., and Ohmoto, H., 1998, Origins of pyrite in the $\sim 2.5 \mathrm{Ga}$ Mt. McRae Shale, the Hamersley District, Western Australia: Geochimica et Cosmochimica Acta, v. 62, p. 3205-3220, doi: 10.1016 S0016-7037(98)00229-4.

Kampschulte, A., and Strauss, H., 2004, The sulfur isotopic evolution of Phanerozoic seawater based on the analysis of structurally substituted 
sulfate in carbonates: Chemical Geology, v. 204, p. 255-286, doi: 10.1016/j.chemgeo.2003.11.013.

Kelley, K.D., Leach, D.L., Johnson, C.A., Clark, J.L., Fayek, M., Slack, J.F., Anderson, V.M., Ayuso, R.A., and Ridley, W.I., 2004, Textural, compositional, and sulfur isotope variations of sulfide minerals in the Red Dog $\mathrm{Zn}-\mathrm{Pb}-\mathrm{Ag}$ deposits, Brooks Range, Alaska: Implications for ore formation: Economic Geology and the Bulletin of the Society of Economic Geologists, v. 99, p. 1509-1532.

Lambert, I.B., and Donnelly, T.H., 1991, Atmospheric oxygen levels in the Precambrian: A review of isotopic and geological evidence: Palaeogeography, Palaeoclimatology, Palaeoecology, v. 97, p. 83-91, doi: 10.1016/00310182(91)90184-S.

Large, R., McGoldrick, P., Bull, S., and Cooke, D., 2004, Proterozoic stratiform sediment-hosted zinc-lead-silver deposits of northern Australia, in Deb, M., and Goodfellow, W.D., eds., Sediment hosted lead-zinc sulphide deposits; attributes and models of some major deposits in India, Australia and Canada: New Delhi, Narosa Publishing House, p. 1-23.

Larkin, M.J., Aharon, P., and Henk, M.C., 1994, Beggiatoa in microbial mats at hydrocarbon vents in the Gulf of Mexico and Warm Mineral Springs, Florida: Geo-Marine Letters, v. 14, p. 97-103, doi: 10.1007/BF01203720.

Logan, G.A., and Hinman, M.C., 2001, Biogeochemistry of the $1640 \mathrm{Ma}$ McArthur River (HYC) lead-zinc ore and host sediments, Northern Territory, Australia: Geochimica et Cosmochimica Acta, v. 65, p. 2317-2336, doi: 10.1016/S0016-7037(01)00599-3.

Logan, G.A., Hayes, J.M., Hieshima, G.B., and Summons, R.E., 1995, Terminal Proterozoic reorganization of biogeochemical cycles: Nature, v. 376, p. 53-56, doi: 10.1038/376053a0.

Lowell, R.P., and Keller, S.M., 2003, High-temperature seafloor hydrothermal circulation over geologic time and Archean banded iron formations: Geophysical Research Letters, v. 30, no. 7, p. 1391, doi: 10.1029/2002GL016536.

Lowenstein, T.K., Hardie, L.A., Timofeeff, M.N., and Demicco, R.V., 2003, Secular variation in seawater chemistry and the origin of calcium chloride basinal brines: Geology, v. 31, p. 857-860, doi: 10.1130/G19728R.1.

Luepke, J.J., and Lyons, T.W., 2001, Pre-Rodinian (Mesoproterozoic) supercontinental rifting along the western margin of Laurentia: Geochemical evidence from the Belt-Purcell Supergroup: Precambrian Research, v. 111, p. 79-90, doi: 10.1016/S0301-9268(01)00157-7.

Lydon, J.W., 1996, Sedimentary exhalative sulphides (SEDEX), in Eckstrand, O.R., Sinclair, W.D., and Thorpe, R.I., eds., Geology of Canadian mineral deposit types: Geological Survey of Canada, Geology of Canada, v. 8, p. $130-152$.

Lyons, T.W., 1997, Sulfur isotopic trends and pathways of iron sulfide formation in upper Holocene sediments of the anoxic Black Sea: Geochimica et Cosmochimica Acta, v. 61, p. 3367-3382, doi: 10.1016/S00167037(97)00174-9.

Lyons, T.W., Werne, J.P., Hollander, D.J., and Murray, R.W., 2003, Contrasting sulfur geochemistry and $\mathrm{Fe} / \mathrm{Al}$ and $\mathrm{Mo} / \mathrm{Al}$ ratios across the last oxicto-anoxic transition in the Cariaco Basin, Venezuela: Chemical Geology, v. 195, p. 131-157, doi: 10.1016/S0009-2541(02)00392-3.

Lyons, T.W., Kah, L.C., and Gellatly, A.M., 2004, The Precambrian sulphur isotope record of evolving atmospheric oxygen, in Eriksson, P.G., et al, eds., The Precambrian Earth: Tempos and events: Developments in Precambrian geology: Amsterdam, Elsevier, p. 421-440.

Lyons, T.W., Luepke, J.J., Schreiber, M.E., and Zieg, G.A., 2000, Sulfur geochemical constraints on Mesoproterozoic restricted marine deposition: Lower Belt Supergroup, northwestern United States: Geochimica et Cosmochimica Acta, v. 64, p. 427-437, doi: 10.1016/S0016-7037(99)00323-3.

McGoldrick, P.J., 1999, Northern Australian SEDEX deposits: Microbial oases in Proterozoic seas, in Mineral deposits: Processes to processing: Proceedings of the 5th Biennial SGA Meeting and the 10th Quadrennial IAGOD Symposium, London, 22-26 August 1999: Rotterdam, A.A. Balkema, v. 2, p. $885-888$.

McGoldrick, P.J., Dunster, J., and Aheimer, M., 1999, New sedimentological, geochemical and textural observations from the Lady Loretta deposit: Implications for ore genesis, in Holm, O., Pongratz, J., and McGoldrick, P., eds., Basins, fluids and $\mathrm{Zn}-\mathrm{Pb}$ ores: Hobart, Australia, Centre for Ore Deposit Research, CODES Special Publication 2, p. 49-58.

McShane, M.B.J., 1996, Stratigraphy and mineralisation, Bernborough, Mount Isa South, northwest Queensland [Postgraduate thesis: Brisbane, University of Queensland, $86 \mathrm{p}$.

Oehler, J.H., and Logan, R.G., 1977, Microfossils, cherts, and associated mineralization in the Proterozoic McArthur (H.Y.C.) lead-zinc-silver deposit:
Economic Geology and the Bulletin of the Society of Economic Geologists, v. 72, p. 1393-1409.

Ohmoto, H., Kakegawa, T., and Lowe, D.R., 1993, 3.4-billion-year-old biogenic pyrites from Barberton, South Africa: Sulfur isotope evidence: Science, v. 262, v. 555-557.

Ohmoto, H., Watanabe, Y., and Kumazawa, K., 2004, Evidence from massive siderite beds for a $\mathrm{CO}_{2}$-rich atmosphere before $\sim 1.8$ billion years ago: Nature, v. 429 , p. 395-399, doi: 10.1038/nature02573.

Painter, M.G.M., Golding, S.D., Hannan, K.W., and Neudert, M.K., 1999, Sedimentologic, petrographic and sulfur isotope constraints on fine-grained pyrite formation at Mount Isa Mine and environs, Northwest Queensland, Australia: Economic Geology and the Bulletin of the Society of Economic Geologists, v. 94, p. 883-912.

Pandalai, H.S., Changkakoti, A., Krouse, H.R., and Gunalan, N., 1991, The relationship between carbon, sulfur and pyritic iron in the Amjhore Deposit, Bihar, India: Economic Geology and the Bulletin of the Society of Economic Geologists, v. 86, p. 862-869.

Pavlov, A.A., Hurtgen, M.T., Kasting, J.F., and Arthur, M.A., 2003, Methane-rich Proterozoic atmosphere?: Geology, v. 31, p. 87-90, doi: 10.1130/0091-7613(2003)031<0087:MRPA>2.0.CO;2.

Pavlov, A.A., Kasting, J.F., Brown, L.L., Rages, K.A., and Freedman, R., 2000, Greenhouse warming by $\mathrm{CH}_{4}$ in the atmosphere of early Earth: Journal of Geophysical Research, v. 105, p. 11981-11990, doi: 10.1029/1999JE001134.

Paytan, A., Kastner, M., Campbell, D., and Thiemens, M.H., 1998, Sulfur isotopic composition of Cenozoic seawater sulfate: Science, v. 282, p. 14591462, doi: 10.1126/science.282.5393.1459.

Paytan, A., Kastner, M., Campbell, D., and Thiemens, M.H., 2004, Seawater sulfur isotope fluctuations in the Cretaceous: Science, v. 304, p. $1663-$ 1665, doi: $10.1126 /$ science. 1095258 .

Poulton, S.W., Fralick, P.W., and Canfield, D.E., 2004, The transition to a sulphidic ocean $\sim 1.84$ billion years ago: Nature, v. 431, p. 173-177, doi: 10.1038/nature02912.

Ross, G.M., Bloch, J.D., and Krouse, H.R., 1995, Neoproterozoic strata of the southern Canadian Cordillera and the isotopic evolution of seawater sulfate: Precambrian Research, v. 73, p. 71-99, doi: 10.1016/03019268(94)00072-Y

Rye, D.M., and Williams, N., 1981, Studies of the base metal sulfide deposits at McArthur River, Northern Territory, Australia. III: The stable isotope geochemistry of the H.Y.C., Ridge, and Cooley deposits: Economic Geology and the Bulletin of the Society of Economic Geologists, v. 76, p. 1-26.

Rye, R., Kuo, P.H., and Holland, H.D., 1995, Atmospheric carbon dioxide concentrations before 2.2 billion years ago: Nature, v. 378, p. 603-605, doi: 10.1038/378603a0.

Sageman, B.B., and Lyons, T.W., 2003, Geochemistry of fine-grained sediments and sedimentary rocks, in Mackenzie, F.T., ed., Sediments, diagenesis, and sedimentary rocks: Amsterdam, Elsevier, Treatise on Geochemistry, v. 7 : p. $115-158$

Schieber, J., 1986, The possible role of benthic microbial mats during the formation of carbonaceous shales in shallow mid-Proterozoic basins: Sedimentology, v. 33, p. 521-536.

Schieber, J., 1990, Pyritic shales and microbial mats: significant factors in the genesis of stratiform $\mathrm{Pb}-\mathrm{Zn}$ deposits of the Proterozoic: Mineralium Deposita, v. 25, p. 7-14.

Scott, K.M., Smith, J.W., Sun, S.-S., and Taylor, G.F., 1985, Proterozoic copper deposits in NW Queensland, Australia: Sulfur isotopic data: Mineralium Deposita, v. 20, p. 116-126, doi: 10.1007/BF00204322.

Shanks, W.C., Woodruff, L.G., Jilson, G.A., Jennings, D.S., Modene, J.S., and Ryan, B.D., 1987, Sulfur and lead isotope studies of stratiform $\mathrm{Zn}-\mathrm{Pb}-\mathrm{Ag}$ deposits, Anvil Range, Yukon: Basinal brine exhalation and anoxic bottom-water mixing: Economic Geology and the Bulletin of the Society of Economic Geologists, v. 82, p. 600-634.

Shen, Y., Buick, R., and Canfield, D.E., 2001, Isotopic evidence for microbial sulphate reduction in the early Archaean era: Nature, v. 410, p. 77-81, doi: $10.1038 / 35065071$

Shen, Y., Canfield, D.E., and Knoll, A.H., 2002, Middle Proterozoic ocean chemistry: Evidence from the McArthur Basin, northern Australia: American Journal of Science, v. 302, p. 81-109.

Shen, Y., Knoll, A.H., and Walter, M.R., 2003, Evidence for low sulphate and anoxia in a mid-Proterozoic marine basin: Nature, v. 423, p. 632-635, doi: 10.1038 /nature 01651

Shields, G., Kimura, H., Yang, J., and Gammon, P., 2004, Sulphur isotopic evolution of Neoproterozoic-Cambrian seawater: New francolite-bound 
sulphate $\delta^{34} \mathrm{~S}$ data and a critical appraisal of the existing record: Chemical Geology, v. 204, p. 163-182, doi: 10.1016/j.chemgeo.2003.12.001.

Smith, J.W., and Croxford, N.J.W., 1975, An isotopic investigation of the environment of deposition of the McArthur mineralization: Mineralium Deposita, v. 10, p. 269-276, doi: 10.1007/BF00207885.

Smith, J.W., Burns, M.S., and Croxford, N.J.W., 1978, Stable isotope studies of the origins of mineralization at Mount Isa. I: Mineralium Deposita, v. 13, p. 369-381, doi: 10.1007/BF00206570.

Solomon, P.J., 1965, Investigations into sulphide mineralization at Mount Isa, Queensland: Economic Geology and the Bulletin of the Society of Economic Geologists, v. 60, p. 737-765.

Strauss, H., 1997, The isotopic composition of sedimentary sulfur through time: Palaeogeography, Palaeoclimatology, Palaeoecology, v. 132, p. 97-118, doi: 10.1016/S0031-0182(97)00067-9.

Strauss, H., 2002, The isotopic composition of Precambrian sulphides-Seawater chemistry and biological evolution, in Altermann, W., and Corcoran, P.L., eds., Precambrian sedimentary environments: A modern approach to ancient depositional systems: Oxford, Blackwell Science, International Association of Sedimentologists Special Publication 33, p. 67-105.

Strauss, H., and Schieber, J., 1990, A sulfur isotope study of pyrite genesis: The mid-Proterozoic Newland Formation, Belt Supergroup, Montana: Geochimica et Cosmochimica Acta, v. 54, p. 197-204

Torres, M.E., Bohrmann, G., Dubé, T.E., and Poole, F.G., 2003, Formation of modern and Paleozoic stratiform barite at cold methane seeps on continental margins: Geology, v. 31, p. 897-900, doi: 10.1130/G19652.1.

Turner, R.J.W., 1992, Formation of Phanerozoic stratiform sediment-hosted zinc-lead deposits: Evidence for the critical role of ocean anoxia: Chemical Geology, v. 99, p. 165-188, doi: 10.1016/0009-2541(92)90037-6.

Velasco, F., Herrero, J.M., Gil, P.P., Alvarez, L., and Yusta, I., 1994, Mississippi Valley-type, sedex, and iron deposits in Lower Cretaceous rocks of the Basque-Cantabrian Basin, northern Spain, in Fontbote, L., and Boni, M. eds., Sediment-hosted $\mathrm{Zn}-\mathrm{Pb}$ Ores: Special Publication 10, Society for Geology Applied to Ore Deposits: Springer-Verlag, Berlin-Heidelberg, p. $246-270$
Whelan, J.F., Rye, R.O., and deLorraine, W., 1984, The Balmat-Edwards zinclead deposits-synsedimentary ore from Mississippi Valley-type fluids: Economic Geology and the Bulletin of the Society of Economic Geologists, v. 79 , p. $239-265$.

Wilkin, R.T., and Arthur, M.A., 2001, Variations in pyrite texture, sulfur isotope composition, and iron systematics in the Black Sea: Evidence for Late Pleistocene and Holocene excursions of the $\mathrm{O}_{2}-\mathrm{H}_{2} \mathrm{~S}$ redox transition: Geochimica et Cosmochimica Acta, v. 65, p. 1399-1416, doi: 10.1016/ S0016-7037(01)00552-X

Willan, R.C.R., and Coleman, M.L., 1983, Sulfur isotope study of the Aberfeldy barite, zinc, lead deposit and minor sulfide mineralization in the Dalradian metamorphic terrain, Scotland: Economic Geology and the Bulletin of the Society of Economic Geologists, v. 78, p. 1619-1656.

Winston, D., 1990, Evidence for intracratonic, fluvial and lacustrine settings of Middle and Late Proterozoic basins of western U.S.A., in Gower, C.F., Rivers, T., and Ryan, B., eds., Mid-Proterozoic Laurentia-Baltica: Geological Association of Canada Special Paper 38, p. 535-564.

Winston, D., and Link, P.K., 1993, Middle Proterozoic rocks of Montana, Idaho and eastern Washington, in Reed, J.C., Jr., et al., eds., Precambrian: Conterminous U.S.: Boulder, Colorado, Geological Society of America, Geology of North America, v. C-2, p. 487-517.

Zaback, D.A., Pratt, L.M., and Hayes, J.M., 1993, Transport and reduction of sulfate and immobilization of sulfide in marine black shales: Geology, v. 21 , p. 141-144, doi: 10.1130/0091-7613(1993)021<0141:TAROSA>2.3.CO;2.

Zhang, C.L., Huang, Z., Cantu, J., Pancost, R.D., Brigmon, R.L., Lyons, T.W., and Sassen, R., 2005, Lipid biomarkers and carbon-isotope signatures of a microbial (Beggiatoa) mat associated with gas hydrates in the Gulf of Mexico: Applied and Environmental Microbiology, v. 71, p. 2106-2112, doi: 10.1128/AEM.71.4.2106-2112.2005.

Manuscript Accepted by the Society 29 October 2005 